\title{
Czternastowieczna nieznana pieczęć Wieruszowa Przyczynek do badań nad najstarszą heraldyką miasta i jego właścicieli
}

Heraldyka miast polskich już od ponad stulecia przykuwa uwagę rodzimych badaczy. Wskazać można w tym czasie, co prawda, okresy krótszego lub dłuższego zastoju, mniej lub bardziej ubogie historiograficznie w zakresie studiów nad herbami miejskimi, ale niepodważalnym faktem jest ich ciągłość. Heraldykę municypalną z powodzeniem uprawiano zarówno przed II wojną światową, jak i po niej, w dobie PRL-u, kiedy to z pobudek ideologicznych zaprzestano badań nad innymi, niechętnie widzianymi przez ówczesne władze państwowe, działami heraldyki: rycerską, szlachecką i kościelną ${ }^{1}$. Szczególny wzrost zainteresowania herbami miast nastąpił po 1990 roku. Impulsem do niego były zmiany ustrojowe oraz ściśle powiązana z nimi reforma struktur administracyjnych kraju. Przeprowadzony w latach 1990-1998 podział terytorialny państwa na: gminy, powiaty i województwa, przywrócił organizację samorządową. Jednostki samorządu terytorialnego wymienionych trzech szczebli otrzymały osobowość prawną, a ich organom przyznano prawo do posługiwania się własną symboliką, w tym - przede wszystkim - herbem. W efekcie rozpoczął się masowy proces kreowania herbów samorządowych,

${ }^{1}$ M. HAIsIG: Sfragistyka i heraldyka miast polskich $w$ świetle dotychczasowych badań. „Nauka i Sztuka” 1947, R. 6, s. 77-95; TeNżE: Osiagnięcia i postulaty w zakresie sfragistyki polskiej. St. Źr. 1959, T. 4, s. 153-168 (zwłaszcza s. 158-160); S.K. KuczYŃsKI: Osiagnięcia i postulaty $w$ zakresie heraldyki polskiej. W: Tradycje i perspektywy nauk pomocniczych historii w Polsce. Materiaty z sympozjum w Uniwersytecie Jagiellońskim dnia 21-22 października 1993 roku profesorowi Zbigniewowi Perzanowskiemu przypisane. Red. M. Rokosz. Kraków 1995, s. 93-105 (zwłaszcza s. 103-105). 
który w przypadku gmin miejskich polegał najczęściej na restytuowaniu historycznych godeł miast, pełniących w nowej rzeczywistości prawno-ustrojowej funkcję symbolu gminnej wspólnoty miejskiej i będących wyrazem tożsamości jej mieszkańców. Towarzyszył mu, przynajmniej w odniesieniu do niektórych regionów Polski, wzrost zainteresowania herbami samorządowymi, w tym miejskimi, ze strony historyków, którzy podjęli trud ich zinwentaryzowania i naukowego opracowania ${ }^{2}$.

Wydawać by się mogło, że kompleksowo podejmowane studia i szeroko zakrojone kwerendy archiwalne, ujawniające wiele nieznanych dotąd wizerunków herbów miejskich, zachowanych przeważnie na zabytkach sfragistycznych, przynoszą pełny przegląd dawnej, w szczególności przedrozbiorowej, heraldyki municypalnej. Tymczasem tu i ówdzie, zupełnie przypadkowo, natrafić wciąż można na źródła pominięte przez badaczy, które problem kształtowania się symboliki heraldycznej konkretnego miasta stawiają w całkowicie nowym świetle ${ }^{3}$. Z takim właśnie przypadkiem mamy do czynienia $\mathrm{w}$ odniesieniu do herbu Wieruszowa, któremu warto się przyjrzeć nieco bliżej zwłaszcza w kontekście hucznie obchodzonej w 2018 roku 650. rocznicy powstania miasta i toczącej się przy tej okazji publicznej dyskusji na temat jego nowego herbu ${ }^{4}$.

Wieruszów, leżący obecnie $\mathrm{w}$ granicach województwa łódzkiego, historycznie związany jest z ziemią wieluńską, stanowiącą w latach 1396-1793 integralną część województwa sieradzkiego, przynależnego — w ramach administracyjnej jednostki wyższego rzędu, czyli prowincji — do Wielkopolski ${ }^{5}$. W źródłach pisanych jako miasto (oppidum) wspomniany został po raz pierwszy w roku 1368, gdy w obecności Przecława z Pogorzeli, biskupa wrocławskiego, zawarta została ugoda między Klemensem, dziedzicem Wieruszowa i Świby (nobilis vir Clemens dominus legitimus in oppido Wieruszow et dicta villae Swiba haeres), a Henrykiem, plebanem kościoła pw. św. Mikołaja w Starym Wieruszowie (Wierusow antiqua), w sprawie opłacania dziesięcin i mesznego z Nowego Wieruszowa (nova Wierusow) ${ }^{6}$. Treść dokumentu wska-

${ }^{2}$ Zob. np. W. STRZyŻEwsKi: Treści symboliczne herbów miejskich na Śląsku, Ziemi Lubuskiej i Pomorzu Zachodnim do końca XVIII wieku. Zielona Góra 1999; M. ADAMCZEwski: Heraldyka miast wielkopolskich do końca XVIII w. Warszawa 2000; H. SEROKA: Herby miast małopolskich do końca XVIII wieku. Warszawa 2002; W. DrelicharZ, Z. Piech: Dawne i nowe herby Małopolski. Oprac. graficzne B. WidŁAK. Kraków 2004, s. 219-314; M. KAGANIEC: Herby miast województwa ślaskiego. Katowice 2007.

${ }^{3}$ Zob. np. A. Szweda: Nieznana czternastowieczna pieczęć Łowicza. W: Heraldyka i okolice. Red. A. Rachuba, S. Górzyński, H. ManikowsKa. Warszawa 2002, s. 255-263.

${ }^{4}$ O pracach nad nowym herbem Wieruszowa zob. przyp. 24.

${ }^{5}$ R. Rosin: Ziemia wieluńska w XII-XVI w. Studia z dziejów osadnictwa. Łódź 1961, s. 85-86; W. SzczyGielski: Dzieje ziemi wieluńskiej. Łódź 1969, s. 14-15.

${ }^{6}$ L. Koczy: Dzieje miasta Wieruszowa. Poznań 1930, s. 5-6, 15; W. Patykiewicz: Materiaty do dziejów terenów diecezji częstochowskiej. Archidiakonat wieluński. „Częstochow- 
zuje, że przed 1368 rokiem funkcjonowały tu dwie osady — Stary Wieruszów, nazwany w 1368 roku miastem (antiquum oppidum Wyerusszow), położony na lewym brzegu Prosny, i Nowy Wieruszów, posadowiony na przeciwległym brzegu rzeki ${ }^{7}$ Ich początki badacze wyznaczają na lata 1303 — 1337, ewentualnie — zawężając nieco bardziej chronologię — na lata 1318 - 1321, tj. na okres, gdy panem ziemi wieluńskiej był Bolesław, książę niemodliński, a założyciela upatrują w którymś $\mathrm{z}$ dwóch występujących wówczas w źródłach Lutoldów z Wieruszowa ${ }^{8}$. Młodszego z nich (Ludoldus dyctus Werucz), pojawiającego się jednorazowo 11 listopada 1337 roku w Wieluniu ${ }^{9}$, zidentyfikowano jako syna Lutolda Starszego (Lutoldus de Weruchs), Ślązaka notowanego 15 kwietnia 1303 roku w otoczeniu starosty świdnickiego Hermana Barby (de Barboye) ${ }^{10}$. Na tej podstawie sądzi się, że rodzina Wieruszów przybyła w Wieluńskie ze Śląska ${ }^{11}$, przenosząc najprawdopodobniej na założoną przez siebie osadę nazwę śląskiego gniazda, którym był Wieruszów (Werussowe, Wierischau) koło Świdnicy ${ }^{12}$. Ponieważ własnością Lutolda Młodszego były rozległe włości składające się ze wsi: Biała, Brzoza, Kąty, Lututów, Świątkowice, Walichnowy, Wieruszów i Wiktorów ${ }^{13}$, których — zdaniem części badaczy — nie sposób było zgromadzić w ciągu krótkiego czasu, nie wykluczają oni całkowicie domysłu, że rodzina przebywała w Wieluńskiem

skie Wiadomości Diecezjalne” 1958, T. 32, s. 237 (regest), 276-277 (pełny tekst dokumentu); R. Rosin: Ziemia wieluńska..., s. 125-127; J. ZBUDNIEweK: Kopiarz dokumentów konwentu Paulinów w Wieruszowie. Cz. 2: Treść dokumentów kopiarza. „Archiwa, Biblioteki i Muzea Kościelne” 1973, T. 27, nr 1, s. 207 (regest).

${ }^{7}$ R. Rosin: Ziemia wieluńska..., s. 125-126; Stownik historyczno-geograficzny ziemi wieluńskiej w średniowieczu. Oprac. R. Rosin. Warszawa 1963, s. 155-156, 174; TenżE: Dzieje Praszki do początku XIX wieku. W: Nad górną Prosna. Monografia Praszki. Red. T. KrzemińSKI. Łódź 1999, s. 239.

${ }^{8}$ L. Koczy: Dzieje miasta..., s. 5, 14; J. Sperka: Otoczenie Władysława Opolczyka w latach 1370-1401. Studium o elicie władzy w relacjach z monarchą. Katowice 2006, s. 188-189.

9 KDW, T. 2, nr 1174.

${ }^{10}$ Urkunden des Klosters Kamenz. Hrsg. P. Pfotenhauer. In: CDSil, Bd. 10, nr 78. W kwestiach genealogicznych zob. S. KozIEROwsKi: Obce rycerstwo $w$ Wielkopolsce $w$ XIIIXVI wieku. Poznań 1929, s. 119; L. Koczy: Dzieje miasta..., s. 13-14; T. Stolarczyк: Szlachta wieluńska od XIV do połowy XVI wieku. Wieluń 2005, s. 15-16.

${ }^{11}$ S. KozIerowski: Obce rycerstwo..., s. 119-120; L. Koczy: Dzieje miasta..., s. 13-14; T. StolarczyK: Szlachta wieluńska..., s. 15; J. SPerka: Otoczenie..., s. 188.

${ }^{12}$ Liber fundationis episcopatus Vratislaviensis. Hrsg. H. Markgraf, J.W. Schulte. In: CDSil, Bd. 14, s. 84. Innego zdania jest L. WojcIechowsKi (Ród Wieruszów do początku XV wieku. W: Ludzie i herby w dawnej Polsce. Red. P. Dymmel. Lublin 1995, s. 39, 41, 43), który identyfikuje miejscowość Werussowe z Wieruszycami. Problem jednak w tym, że w okolicach Świdnicy, gdzie miałaby ona według niego leżeć, wieś o takiej nazwie nie istnieje, zob. w tej kwestii R. Rosın: Dzieje Praszki..., s. 238.

${ }^{13}$ L. Wojciechowski: Ród Wieruszów..., s. 43-45; T. Stolarczyk: Szlachta wieluńska.., s. 16. Por. Stownik historyczno-geograficzny..., s. 57—58, 64, 90—91, 107, 155—156, $160-161,167,174-175,177$. 
już pod koniec XIII stulecia. Przemawia za tym kontekst dokumentu z 1337 roku. Wynika z niego, że ojciec wystawcy był zasiedziałym w ziemi wieluńskiej rycerzem, łączonym ze Starym Wieruszowem ${ }^{14}$. Wczesne związki Lutolda Starszego z ziemiami świdnicką i ziębicką zdają się jednak wskazywać, że wyszedł on z linii Wieruszów osiadłej na Śląsku, gdzie ślady obecności przedstawicieli familii - Lutolda (Leuthold von Werusch) i Hanusza (Hannos/ Hannus Weruscher) - mamy potwierdzone jeszcze pod koniec XIV wieku ${ }^{15}$. Niezależnie zresztą od trafności jednej (imigracyjnej) bądź drugiej (autochtonicznej) koncepcji, mających dla niniejszych rozważań drugorzędne znaczenie, bezsporny pozostaje fakt, że będący w centrum naszego zainteresowania Wieruszów w ziemi wieluńskiej należał od samego początku do rycerskiej familii nazywanej powszechnie Wieruszami. Był więc miastem prywatnym, pozostającym w rękach tej rodziny nieprzerwanie aż do 1467 roku. Wtedy właśnie Małgorzata z Wieruszowa, sukcesorka wieruszowskich dóbr ziemskich leżących na terenie powiatów ostrzeszowskiego i wieluńskiego, siostra Zbigniewa (zm. 1464) i Jana Kozłka (zm. 1465-1466), sprzedała część rodowych posiadłości, a wśród nich miasto Wieruszów wraz z fortalicją, Janowi Kępińskiemu z Baranowa herbu Niesobia za 1000 grzywien szerokich groszy praskich $^{16}$.

W okresie swoich 650-letnich dziejów, liczonych od powstania miasta najpóźniej w 1368 roku, Wieruszów posługiwał się, jak wynika z badań heraldycznych, dwoma różnymi herbami. Starszy z nich, wykształcony w okresie staropolskim, przedstawia na srebrnym polu kroczącego w prawą stronę czarnego kozła na zielonej murawie, który dźwiga na grzbiecie czerwony kościół $\mathrm{z}$ dwiema wieżami ${ }^{17}$. Młodszy $\mathrm{z}$ kolei, o nieznanych barwach, będący dziełem carskich urzędników z połowy XIX wieku, na szachowanym polu, przypuszczalnie w czerwono-srebrne (białe) cegły, kładzie wieżę obronną z otwar-

${ }^{14}$ R. Rosin: Ziemia wieluńska..., s. 126; TenżE: Dzieje Praszki..,, s. 239-240; L. WoJCIECHOwski: Ród Wieruszów..., s. 39-43.

${ }^{15}$ Landbuch księstw świdnickiego i jaworskiego. Wyd. T. JuREK. T. 1: 1366-1376. Poznań 2004, nr 834; T. 2: 1385-1395. Poznań 2000, nr 987, 1026, 1340; zob. też J. Sperka: Otoczenie..., s. 188 , przyp. 83.

16 T. StOlarczyк: Szlachta wieluńska..., s. 55; T. NowAK: Własność szlachecka $w$ ziemi wieluńskiej na początku 2. połowy XV wieku. „Rocznik Łódzki” 2014, R. 61, s. 72. O nabywcy Wieruszowa zob. T. JuReK: Krag rodzinny starosty wielkopolskiego Wierzbięty (1352-1369), czyli poczatki rodu Niesobiów. „Genealogia. Studia i Materiały Historyczne” 1991, T. 1, s. 31-32; T. Stolarczy : Szlachta wieluńska..., s. 56.

17 T. Olejnik: Pieczęcie i herby miast ziemi wieluńskiej. Łódź 1971, s. 60-61; M. AdAMCZEwski: Heraldyka miast..., s. 159, 456; TenżE: Pieczęcie urzędowe władz lokalnych z obszaru Polski centralnej. Cz. 3: Pieczęcie władz miejskich do 1950 roku. Zgierz 2010, s. 59. Warto dodać, że zdarzają się także wypadki, gdy kozioł przedstawiany jest błędnie — nie jako zwierzę dźwigające na grzbiecie bryłę kościoła, ale stojące przed nią, zob. np. J. KoBIERzYCKI: Przyczynki do dziejów ziemi sieradzkiej. Warszawa 1915, ryc. na okładce; M. Gumowski: Herby miast polskich. Warszawa 1960, s. 339. 
tą bramą i trzema oknami, zwieńczoną pięcioblankowym krenelażem, a na jej szczycie połukozła w słup w prawo ${ }^{18}$. Ten ostatni nie wszedł wprawdzie do użytku, gdyż nie zyskał akceptacji cara Mikołaja I, podobnie zresztą jak wszystkie inne herby miast Królestwa Polskiego (Kongresowego) opracowane dla tzw. Albumu Heroldii Królestwa Polskiego w latach 1846-1849 (było ich łącznie 456) ${ }^{19}$, jednakowoż funkcjonował, zdaje się, jako symbol miasta w odrodzonej Rzeczypospolitej. Jego wizerunek, podpisany jako „herb miasta Wieruszowa”, zdobi wszak wewnętrzną okładkę wydanej w 1930 roku monografii tego ośrodka miejskiego ${ }^{20}$. Jednocześnie trwały prawdopodobnie prace nad przywróceniem historycznego herbu Wieruszowa. Pierwsze jego projekty, autorstwa Wacława Granicznego, opracowane na podstawie dawnych pieczęci magistrackich, powstały już w 1915 roku $^{21}$, poprzedzając właściwy proces legislacyjny zatwierdzania herbów miejskich, jaki trwał w latach 1927-193922. Herb w znanym nam przedrozbiorowym kształcie wprowadzono w Wieruszowie oficjalnie w roku 1937 na mocy zarządzenia ministra spraw wewnętrznych, sygnowanego przez Władysława Korsaka, ówczesnego podsekretarza stanu; opis herbu w dokumencie brzmiał: ,,...] w polu srebrnym na murawie zielonej czarny kozioł kroczy w prawo; za grzbietem kozła - czerwony fronton kościoła z takimiż dwiema wieżami" ${ }^{23}$. Stał się on także symbolem miasta

${ }^{18}$ M. Adamczewski: Pieczęcie urzędowe..., s. 161.

19 Tamże, s. 163. O samym Albumie Heroldii Królestwa Polskiego, będącym w praktyce ankietą heraldyczną skierowaną przez władze carskie do włodarzy miast, pisał ostatnio obszernie, zwłaszcza w kontekście dawnych województw łęczyckiego i sieradzkiego, M. ADAMCZEwSKI (tamże, s. 152-156); zob. też TenżE: Miejsce „Albumu Herbów Miast Królestwa Polskiego" z 1847 r. w polskiej heraldyce miejskiej. W: Herby miast polskich w okresie zaborów (1772-1918). Materiały z sesji naukowej, Włocławek 5-6 grudnia 1996 r. Red. S.K. KuCZYŃSKI. Włocławek 1999, s. 109-130. Warto dodać, że niepowodzeniem zakończyła się też przeprowadzona w latach 1867-1869 ankieta sfragistyczno-heraldyczna, zarządzona — tak jak poprzednia - przez władze, której celem miała być weryfikacja prawidłowości herbów używanych przez miasta guberni kaliskiej i piotrkowskiej. Miasta nie tylko nie uzyskały wówczas zatwierdzenia swoich herbów, ale wiele z nich, w tym Wieruszów, na mocy ukazu carskiego z 1869 r. utraciło nawet prawa miejskie, zob. m.in.: S.K. Kuczyński: Polonika heraldyczne i sfragistyczne w zbiorach leningradzkich. „Archeion” 1978, T. 66, s. 199-213; M. AdAMCZEWSKi: Pieczęcie urzędowe..., s. 163-177.

${ }^{20}$ L. Koczy: Dzieje miasta..., s. II. Należy zresztą zauważyć, że autor stwierdził wprost, iż „dzisiejszy herb przedstawia jak dawniej wieżę, przednią połowę kozła ponad wieżami” (tamże, s. 6, przyp. 3).

${ }^{21}$ J. Kobierzycki: Przyczynki do dziejów..., ryc. na okładce; M. Adamczewski: Pieczęcie urzędowe..., s. 175-176, 203.

22 Zagadnienie poruszyli szerzej S.K. KuCZyŃski, L. PudŁowski: Udziat archiwów państwowych w tworzeniu herbów okresu międzywojennego. „Archeion” 1987, T. 82, s. 114122.

${ }^{23}$ Zarzadzenie Ministra Spraw Wewnętrznych z dnia 18 czerwca 1937 r. w sprawie zatwierdzenia herbu miasta Wieruszowa. „Monitor Polski”, R. 20, nr 164, poz. 274 z 21 lipca 1937 r.; S.K. KuCZYŃski, L. PudŁowski: Udział archiwów..., s. 132. 
po 1945 roku i — oddawany w mniej lub bardziej udanej konwencji plastycznej - pozostaje nim nieprzerwanie do dziś ${ }^{24}$.

Nie ma najmniejszych wątpliwości, że wieruszowski herb stanowi swoistą kompilację lokalnej symboliki feudalnej (władzy zwierzchniej) i samorządowej $^{25}$. Pierwszą z nich odzwierciedla wyobrażone na tarczy zwierzę, nawiązujące do godła familii Wieruszów, założycieli i posesjonatów miasta, którzy na srebrnej tarczy kładli kozła na poły czarnego, na poły w czerwono-srebrną szachownicę ${ }^{26}$. Związek ten jawić się nam będzie szczególnie wyraźnie, gdy weźmiemy pod uwagę fakt, że tożsame godło, aczkolwiek o odmiennej barwie lub w innej stylizacji heraldycznej, pojawia się także w herbach dwóch innych, położonych w rejonie ścisłego osadnictwa Wieruszów, miast należących do ich przedstawicieli, mianowicie Lututowa i Praszki ${ }^{27}$. W kościele o dwóch wieżach badacze doszukują się z kolei realnie istniejącej budowli, identyfikując ją $\mathrm{z}$ jedną z kilku wieruszowskich świątyń, przy czym pod uwagę biorą jedynie

${ }^{24}$ Polskie herby miejskie. Red. T. Szczechura. Oprac. graficzne R. Sidorowski. Warszawa 1953, nr 293; M. Gumowski: Herby miast..., s. 339; Miasta polskie w Tysiacleciu. T. 2. Wrocław-Warszawa-Kraków 1967, tabl. LXIV; T. Olejnik: Pieczęcie i herby..., s. 61, ryc. 33; A. Plewako, J. Wanag: Herbarz miast polskich. Warszawa 1994, s. 248; J. KwiateK, T. LiJewski: Leksykon miast polskich. Warszawa 1998, s. 997. Należy zauważyć, że herbu Wieruszowa, pomimo zatwierdzenia go w 1937 r., nie odnotowano w publikacji A. CHOMICKIEGo Herby miast i ziem polskich (Warszawa 1939). Dodajmy, że w ostatnim czasie z inicjatywy władz miasta podjęto prace zmierzające do poprawy wizerunku herbu. Niewłaściwe od strony heraldycznej, a funkcjonujące przez lata, elementy godła zastąpiono zupełnie nową ich stylizacją. Kozła z nienaturalnie wyprofilowanymi i nadmiernie wydłużonymi rogami wyrugowano na rzecz koziołka o klasycznie wygiętych rogach, a dźwiganą przezeń budowlę kościoła przesunięto asymetrycznie w lewą heraldycznie stronę, poddając ją uproszczonej antynaturalistycznej obróbce plastycznej, zob. https://wieruszow.naszemiasto.pl/koziol-bez-wigoru-ale-zato-legalny-nowy-herb-wieruszowa/ar/c4-4886614 [data dostępu: 10.09.2019]. Propozycja budzi jednak kontrowersje wśród mieszkańców miasta, przyzwyczajonych do starego herbu.

${ }^{25}$ M. Adamczewski: Heraldyka miast..., s. 159-160; Tenże: Pieczęcie urzędowe..., s. 59.

26 J. SzYMański: Herbarz średniowiecznego rycerstwa polskiego. Warszawa 1993, s. 292.

${ }^{27}$ Herb Lututowa, pochodzący z 1532 r., przedstawia w polu niebieskim srebrnego kozła ze złotymi rogami zwróconego w lewą stronę, natomiast herb Praszki, którego najstarszy wizerunek zachował się na pieczęci z 1536 r., eksponuje w polu srebrnym czarnego kozła ze złotymi rogami kroczącego po kładce rozciągniętej między dwiema czerwonymi basztami (inną jego odmianę, bez kładki między basztami i ze złotym jeleniem zamiast kozła, zamieszczono w publikacji Miasta polskie w Tysiacleciu..., tabl. LXII). O herbach obu miast zob. szerzej: T. Olejnik: Pieczęcie i herby..., s. 48-54; M. Antoniewicz: Herby miast województwa częstochowskiego. Częstochowa 1984, s. 79 i tabl. 11; Z. SzCZerbiK: Herb miasta Praszki. W: Herby miast polskich w okresie zaborów..., s. 199-203; M. AdAMCZewsKI: Herb i pieczęcie miasta. W: Nad górna Prosnq..., s. 255-261; TenżE: Heraldyka miast..., s. 170, 371; D. ToMCZYK, S. ZIARKO: Herby oraz inne symbole samorzadowe miast i gmin województwa opolskiego. Opole 2000, s. 43 i fot. na s. 60; T. Grabarczyк, T. Nowak: Dzieje Lututowa do połowy XVI wieku. W: Sześć wieków Lututowa. Studia i materiaty. Red. T. Olejnik. Wieluń 2007, s. 14. 
kościoły pw. św. Bartłomieja (w Nowym Wieruszowie), św. Mikołaja (w Starym Wieruszowie) oraz Ducha Świętego i Nawiedzenia NMP (przed bramami miasta nad rzeką Prosną), ze wskazaniem na ten ostatni ${ }^{28}$, ufundowany wraz z kompleksem klasztornym w 1401 roku przez Bernarda Wierusza Lutoldowica, sędziego ziemi wieluńskiej i starosty ostrzeszowskiego, oraz jego syna Wierusza dla sprowadzonych przez nich na przedmieścia Wieruszowa paulinów ${ }^{29}$. Motyw kościoła, ośrodka życia religijnego miejskiej wspólnoty, akcentuje więc silną pozycję właścicieli Wieruszowa oraz ich dokonania fundacyjne $^{30}$, ale pełni również funkcję symbolu gminy miejskiej i tożsamości jego mieszkańców ${ }^{31}$.

Choć Wieruszów stał się miastem najpóźniej pod koniec siódmej dekady XIV wieku, to najstarsze wiarygodne wizerunki jego herbu, eksponującego wyobrażenie kozła dźwigającego dwuwieżowy kościół, zachowały się dopiero z końca XVIII stulecia ${ }^{32}$. Widnieją one na trzech odciskach pieczęci z lat 1777-1780. Dwa z nich — okrągłe, oba o średnicy $39 \mathrm{~mm}$, z tożsamym godłem i identyczną legendą w brzmieniu: SIGILLVM CIVITATIS WIERVSZOVIE(nsis), a zatem wyciśnięte ewidentnie za pomocą tego samego

${ }_{28}^{28}$ M. Adamczewski: Heraldyka miast..., s. 159-160; TenżE: Pieczęcie urzędowe..., s. 59.

${ }^{29}$ Dokument fundacyjny wieruszowskich paulinów, datowany 27 maja 1401 r., uchodzi wprawdzie za podrobiony (ZDPaul, z. 1, nr 47), ale sam fakt założenia klasztoru przez Bernarda i Wierusza u progu XV stulecia (niektórzy badacze przesuwają fundację nawet na lata 90. XIV w.) nie budzi żadnych wątpliwości, zob. m.in. J.H. ZвuDNIEweK: Katalog domów i rezydencji polskiej prowincji paulinów. „Nasza Przeszłość” 1969, T. 31, s. 223; TenżE: Kopiarz dokumentów konwentu Paulinów w Wieruszowie. „Archiwa, Biblioteki i Muzea Kościelne” 1973, T. 26, s. 208-209; TenżE: Kopiarz dokumentów..., Cz. 2, nr 2, s. 207-208 (regest); J. WiesioŁowski: Fundacje paulińskie XIV i XV wieku na tle ruchu fundacyjnego klasztorów w Polsce. „Studia Claromontana” 1985, T. 6, s. 149-150; L. WoJCIECHOwsKi: Najstarsze klasztory paulinów w Polsce. Fundacja - uposażenie — rozwój do około 1430 roku. „Studia Claromontana” 1991, T. 11, s. 40, 84-86; TenżE: Ród Wieruszów..., s. 47—48; R. Rosin: Dzieje Praszki..., s. $242-243$.

${ }^{30}$ M. AdAmczewsKi: Heraldyka miast..., s. 160; P. GoŁdYn: Symbolika religijna i kościelna w herbach miast polskich do końca XX wieku. Warszawa 2008, s. 212.

${ }^{31} \mathrm{~W}$ ten sam sposób H. Seroka (Herby miast..., s. 147) interpretuje motyw kościoła w pochodzącym prawdopodobnie z XIV w. herbie Czchowa.

${ }^{32}$ Należy w tym miejscu zaznaczyć, że w najstarszej księdze miejskiej Wieruszowa z początku XVI w. L. Koczy (Dzieje miasta..., s. 6, przyp. 2 i podpis pod ilustracją na stronie nieliczbowanej przed s. 1) natrafił na podobiznę herbu, który miał wyobrażać - jego zdaniem - kozła opierającego się nogami na dwuwieżowej baszcie. Herb ten nie jest jednak nigdzie indziej potwierdzony, a na ten sam okres, tj. na XVI w., datuje się - o czym mowa będzie dalej w tekście — powstanie najstarszego znanego w historiografii tłoka pieczęci miejskiej Wieruszowa, używanego jeszcze u schyłku XVIII w. Ponieważ eksponował on herb miasta z tradycyjnym motywem kozła dźwigającego na swym grzbiecie dwuwieżową fasadę kościoła, należy przypuszczać, że badacz mylnie zinterpretował jeden — najpewniej niezbyt dobrze zachowany — z pierwszych jego odcisków. 
typariusza — pochodzą z lat $1777-1778^{33}$. Trzeci egzemplarz, również okrągły, ale znacznie mniejszy, bo mierzący zaledwie $26 \mathrm{~mm}$ średnicy, z napisem otokowym: CIVITAS WYERVSZOVIEN(sis), jest znany z 1780 roku $^{34}$. Obie pieczęcie różnią się — poza wielkością i treścią inskrypcji — zarówno stylizacją kompozycji, jak i szczegółami wyobrażenia. Na egzemplarzach z lat 1777-1778 tarcza, której pole wypełnia floratura, reprezentuje typ barokowy, tj. z wgłębieniami po bokach oraz uformowanymi na kształt trójliścia szczytem i podstawą. Cechy baroku zdradzają także kościelne wieże, których wysokie i smukłe, szpiczasto zwieńczone hełmy zdają się wyrastać z opartych na krążynach, charakterystycznych dla architektury tego stylu, cebulastych dachów. Z kolei na pieczęci z 1780 roku miejskie godło zostało położone na gotyckiej tarczy typu hiszpańskiego, powszechnie stosowanej $\mathrm{w}$ heraldyce miejskiej w XVI wieku, a będące jego komponentem kościelne wieże wyglądają na masywniejsze, niższe i - co szczególnie istotne - są pozbawione barokowych detali.

Służący do wyciśnięcia stempla typariusz z 1780 roku jest tylko pozornie późniejszy od tłoka użytego do uwierzytelnienia dokumentów z lat 17771778. Na tym ostatnim dopatrzono się wszak realistycznego przedstawienia świątyni klasztornej miejscowych paulinów, której odbudowa - idąca w parze $\mathrm{z}$ barokizacją - po zniszczeniach, jakich doznała ona w połowie XVII wieku, nastąpiła w latach 1676-1680. Jako terminus post quem sporządzenia typariusza wyznacza się więc ten właśnie okres ${ }^{35}$. Powstanie tłoka, za pomocą którego wyciśnięto stempel znany z 1780 roku, datuje się natomiast na początek XVI wieku, za czym przemawiać ma zarówno kształt tarczy herbowej, jak i występowanie w legendzie liter typowych dla uformowanej tekstury kaligraficznej ${ }^{36}$. Ponieważ w tym czasie dziedzicami Wieruszowa byli już Oporowscy herbu Sulima, a po nich Tomiccy herbu Łodziaa ${ }^{37}$, przyjmuje się, że herb miasta, powstały z połączenia rodowego godła Wieruszów i wizerunku

${ }_{33}$ T. Olejnik: Pieczęcie $i$ herby..., s. 60 i ryc. 32; M. Adamczewski: Heraldyka miast..., s. 159, 456 (tutaj błędna informacja, że kozioł kroczy w lewo); TenżE: Pieczęcie urzędowe..., s. 59.

${ }^{34}$ T. Olejnik: Pieczęcie i herby..., s. 60 (z mylnym odczytem VERVSZOVIEN); M. AdAMCZEWSKi: Heraldyka miast..., s. 160, 456 (tutaj niewłaściwa lekcja legendy VYERVSZOVIEN i błędna informacja o koźle kroczącym w lewo); TenżE: Pieczęcie urzędowe..., s. 59.

${ }_{35}$ M. AdAmCZewski: Heraldyka miast..., s. 160, 456. Związek wyobrażenia kościoła w godle z rzeczywistą bryłą wieruszowskiej świątyni paulińskiej sugerował już M. GumowSKI: Herby miast..., s. 339.

${ }^{36}$ M AdAmczewski: Heraldyka miast..., s. 159, 456. Najpewniej odcisk tego właśnie starszego typu pieczęci, zachowany w najstarszej księdze radzieckiej z początku XVI w., widział pod koniec lat 20. XX stulecia L. Koczy (Dzieje miasta..., s. 6, przyp. 2), zob. wcześniej przyp. 32. Zob. też: M. Gumowski: Herby miast..., s. 339 i Polskie herby miejskie..., nr 293, gdzie najstarsza pieczęć miejska Wieruszowa, eksponująca wizerunek kozła z dwuwieżowym kościołem, datowana jest także na XVI w.

${ }^{37}$ L. Koczy: Dzieje miasta..., s. 19-23; T. Stolarczyк: Szlachta wieluńska ..., s. 59-60. 
kościoła z dwiema wieżami, narodził się najpewniej w latach 1401—1467, tj. po fundacji paulińskiej świątyni pw. Ducha Świętego, dokonanej przez Bernarda Wierusza i jego syna, a przed wyjściem Wieruszowa z rąk Wieruszów $^{38}$. Miał on już widnieć na najstarszej pieczęci miejskiej Wieruszowa, zniszczonej przypuszczalnie $\mathrm{w}$ czasie pożaru, jaki strawił miasto u schyłku XV wieku (w 1497 lub 1498 roku), co wiązało się z koniecznością sprawienia nowego tłoka powielającego ten sam motyw herbowy ${ }^{39}$. Stanowisko to, w pełni przekonujące przed dwiema dekadami, wymaga w świetle najnowszych odkryć zrewidowania.

Kolacjonując w Archiwum Państwowym we Wrocławiu pieczęcie rycerstwa śląskiego ${ }^{40}$, w zespole gromadzącym dokumenty pochodzące ze skasowanego w 1810 roku klasztoru krzyżowców z czerwoną gwiazdą pw. św. Macieja we Wrocławiu natknąłem się na niepublikowany dokument $\mathrm{z}$ datą 28 stycznia 1426 roku. Został on wystawiony przez Wierusza z Kątów, pana na Wieruszowie, niewymienionego $\mathrm{z}$ imienia burmistrza miasta oraz wieruszowskich rajców (Werusschius de Canthi, dominus in Weruschaw, protoconsul in ibidem consulesque), którzy potwierdzili nim, że de anno domini MCCCCXXIIII mensis septembris Jan Krzywicki (Crziwitsky), piastujący urząd wójta w Wieruszowie, oraz Paweł, zwany Pella, zażegnali spór między braćmi Janem i Michałem, synami Andrzeja Zmarzlika (Smarslik), a konwentem szpitala św. Macieja o ziemie w podwrocławskich Dobrzykowicach (Wüstendorf) ${ }^{41}$. $\mathrm{O}$ ile treść dokumentu, będącego standardową ugodą, jakich w średniowieczu zawierano wiele, nie wyróżnia się w zasadzie niczym szczególnym, o tyle uwagę przykuwają uwierzytelniające go pieczęcie, obie okrągłe, wyciśnięte w wosku ciemnobrązowej barwy, zawieszone na pergaminowych paskach.

Pierwsza z pieczęci, o średnicy $28 \mathrm{~mm}$, reprezentuje typ herbowy, z tzw. pełnym herbem. W jej polu wyobrażono ostro zakończoną u podstawy tarczę herbową, pochyloną w lewo, na której widnieje wspięty w lewą stronę kozioł, przykrytą hełmem rycerskim typu „żabi pysk”, zwróconym także w lewą stronę. W klejnocie kita $\mathrm{z}$ piór w słup. Kompozycję okala ułożona wertykalnie czterolistna rozeta wkraczająca na otok pieczęci i rozdzielająca umieszczoną na nim legendę na dwie części. Ta ostatnia, ryta majuskułą gotycką z elementami uncjały, oddzielona od pola wyobrażeniowego perełkowym sznurem, z nieznacznie zatartą ostatnią literą imienia dysponenta, brzmi: WERISON[E] / VON KANT (fot. 1).

Druga pieczęć, również herbowa, mierząca $30 \mathrm{~mm}$ średnicy, przedstawia tarczę gotycką o kroju hiszpańskim, a więc łagodnie zaokrągloną u podstawy,

\footnotetext{
${ }^{38}$ M. Adamczewski: Heraldyka miast..., s. 160. Zob. też wcześniej przyp. 16 i 29.

39 M. AdAMCZewski: Heraldyka miast..., s. 160.

${ }^{40}$ M.L. WóıcıK: Pieczęcie rycerstwa śląskiego $w$ dobie przedhusyckiej. T. 1-2. Kraków-Wrocław 2018.

${ }^{41}$ AP Wrocław, Rep. 66, nr 463.
} 
dwudzielną w słup. Na prawym polu znajduje się szachownica sześciorzędowa w trzy cegły, na polu lewym zaś - połukozioł kroczący w lewo. Napis otokowy, wykonany majuskułą gotycką z elementami uncjały, słabo czytelny w środkowej części z powodu zatarcia trzech liter, oddzielony od pola wyobrażeniowego sznurem $\mathrm{z}$ perełek, głosi: $+\cdot \mathrm{S} \cdot \mathrm{C} \cdot$ WERVSC[HOW]IENSIS (fot. 2).

Johann Karl Friedrich Jarick, autor rękopiśmiennego inwentarza dokumentów wrocławskich krzyżowców z czerwoną gwiazdą, sporządzonego w 1818 roku, a zatem w czasie, kiedy uwierzytelniające dokument z 1426 roku pieczęcie były przypuszczalnie zachowane w lepszej niż dziś kondycji, wskazał jako ich dysponentów rajców miasta Wieruszowa oraz braci Zmarzlik („,zwei Siegel auf braunem Wachse, nemlich das der Consuln, und das der Smarslike Gebrüder auf braunem Wachse") ${ }^{42}$. Identyczne stanowisko zajął Roman Stelmach, który w katalogu dokumentów przechowywanych we wrocławskim archiwum stwierdził, że przy interesującym nas dyplomie wiszą „na paskach pergaminowych pieczęcie rady i braci Smarslik"43. Archiwista nie pokusił się, jak sądzę, o autopsję oryginalnych stempli i sięgnął jedynie po inwentarzowy opis Jaricka, do którego zakradł się trudny do wytłumaczenia błąd. Z treści widniejących na pieczęciach inskrypcji wynika wszak, że żaden z odcisków nie należał do Zmarzlików. Właścicielem pierwszego był Wierusz (Werisone, Werusschius), pochodzący, na co wskazują używane przezeń herb i odmiejscowy predykat, z pieczętującej się kozłem familii Wieruszów, piszącej się z Kątów (Walichnowskich) i Wieruszowa. Fakt ten pozwala jednoznacznie identyfikować go ze starostą (1414-1415) i z sędzią wieluńskim (1418 - 1432), nadto $\mathrm{z}$ burgrabią ostrzeszowskim (1421), zmarłym w 1432 roku lub wkrótce potem, synem dobrze znanego w historiografii Bernarda Wierusza Lutoldowica z Wieruszowa, Kopanicy i Walichnów (zm. po 1408), rycerza i urzędnika księcia Władysława Opolczyka i króla Władysława Jagiełły, wspomnianego już wcześniej fundatora klasztoru paulinów wieruszowskich, oraz nieznanej z imienia córki kasztelana sieradzkiego Zbigniewa z Wielgomłynów herbu Zadora. Jego bratem był Lutold z Kątów i Wiktorowa, chorąży wieluński (1420), żoną zaś - poślubioną przed 1403 rokiem - Katarzyna, córka wojewody poznańskiego Maćka Borkowica herbu Napiwon ${ }^{44}$.

Nietrudno wskazać także dysponenta drugiej pieczęci. Nie znamy pełnej treści jej legendy, incipit tworzą bowiem sygle S i C, ale koroboracja uwie-

42 AP Wrocław, Rep. 66: Inhaltsverzeichniß der Urkunden des ehemaligen Mathias-Stifftes zu Breslau. 1. Theil: 1252-1500, nr 463 (rps).

${ }_{43}$ R. Stelmach: Katalog średniowiecznych dokumentów przechowywanych w Archiwum Państwowym we Wrocławiu. Wrocław_Racibórz 2014, s. 446 (nr 8461).

${ }^{44}$ Koligacje rodzinne Wierusza Bernardowica omówili najpełniej: L. WoJcIEchowsKi: Ród Wieruszów..., s. 44-50 i tabl. po s. 54; T. Stolarczyк: Szlachta wieluńska..., s. 15-25; J. SPERKA: Otoczenie..., s. 188-191. 
rzytelnionego nią dokumentu zapowiada użycie sigillów przez wszystkich jego sygnatariuszy: „In cuius rei testimonium sigilla nostra presentibus sunt appensa". Zważywszy więc na fakt, że jako wystawcy występują w źródle poza wspomnianym już Wieruszem z Kątów, właścicielem pierwszego ze stempli - burmistrz i rajcy Wieruszowa, wydaje się oczywiste, że pieczęć ta należała do przedstawicieli władz miasta. Nieporozumieniem jednak jest przypisywanie jej wieruszowskim rajcom, jak to uczynili J.K.F. Jarick i R. Stelmach ${ }^{45}$. Sygle S i C można, co prawda, rozwinąć do formuły S(igillum) $\mathrm{C}$ (onsulum), uzupełnionej o widniejącą w eksplicicie nazwę miasta, ale bardziej zasadne jest odczytywanie ich jako S(igillum) C(ivitatis), z dopełnieniem WERVSC[HOW]IENSIS. Jak bowiem zauważył Marian Haisig, legenda zaczynająca się od słów sigillum consulum, potwierdzona na ziemiach polskich od XIV wieku, przy czym w Wielkopolsce dopiero u progu XVI stulecia, spotykana jest niezwykle rzadko ${ }^{46}$, tymczasem lekcja sigillum civitatis, zarówno w okresie średniowiecza, jak i w czasach nowożytnych, należy do najbardziej rozpowszechnionych, typowych zwłaszcza dla pieczęci małych miast i miasteczek $^{47}$. Ma to bezpośredni związek ze stopniem zorganizowania miejskich kancelarii, które nawet w ośrodkach większych od Wieruszowa - zaliczającego się ok. 1500 roku do czwartej kategorii podatkowej, obejmującej najmniejsze miasta w Koronie ${ }^{48}$ — nie były rozwinięte na tyle, by dysponować odrębnymi pieczęciami dla każdego z organów administracji miejskiej (wójta, rady i ławy). Z tak rozbudowanym systemem sfragistycznym spotykamy się jedynie w największych miastach, natomiast $\mathrm{w}$ miejscowościach średnich i małych aż do XVI wieku używano tylko jednej pieczęci (ogólno)miejskiej" Za takim właśnie rozwiązaniem w przypadku Wieruszowa zdaje się przemawiać dodatkowo treść legendy umieszczonej na następnej, datowanej na XVI wiek, pieczęci miasta, zawierającej kluczowy dla naszych rozważań człon CIVITAS ${ }^{50}$. Toteż eksponowany na zabytku znak, pełniący funkcję atrybutu ustroju, praw i samorządnej wspólnoty miejskiej, identyfikować należy jako najstarsze zachowane dziś przedstawienie herbu Wieruszowa, odmienne - jak widać — od wizerunku późniejszego, dobrze rozpoznanego w literaturze, godła miasta, ale tak jak i ono ściśle powiązane ikonograficznie $\mathrm{z}$ herbem rodziny Wieruszów.

${ }^{45}$ Zob. przyp. 42 i 43.

${ }^{46}$ M. Haisig: Studia nad legenda pieczęci miejskiej. Wrocław 1953, s. 96-97.

47 Tamże, s. 85, 90—91.

${ }^{48}$ Zob. zestawienie dla poszczególnych województw, w tym sieradzkiego, na terenie którego leżał Wieruszów, opracowane przez Henryka Samsonowicza w: M. BogucKa, H. SAMSONOwicz: Dzieje miast i mieszczaństwa w Polsce przedrozbiorowej. Wrocław 1986, s. 115.

${ }^{49}$ M. Haisig: Studia nad legenda..., s. 95-111; M. Adamczewski: Heraldyka miast..., s. 307-475; H. SERoKA: Herby miast..., s. 90-274. Za zwrócenie mi uwagi na ten aspekt problemu dziękuję anonimowemu Recenzentowi.

${ }^{50}$ Zob. przyp. 36. 
Herb Wieruszów wzmiankowano w źródłach pisanych już w 1422 i 1425 roku, a więc krótko przed wystawieniem dokumentu uwierzytelnionego odnalezionymi pieczęciami miasta Wieruszowa i Wierusza Bernardowica, mieniąc go odpowiednio Wyeruschowye i Wyerusch ${ }^{51}$. Przypomnijmy, że w historiografii utrwaliło się przekonanie, że przedstawiciele familii pieczętowali się wizerunkiem kroczącego, brodatego kozła rogatego, na poły czarnego, na poły szachowanego w czerwone i srebrne cegły, kładzionego na srebrnym polu $\operatorname{tarczy}^{52}$. Taki kształt ikonograficzny herbu, występującego pod nazwą Wyeruschowa, odzwierciedla jego opis zawarty w Klejnotach Jana Długosza, przy czym nie jest on doprecyzowany. Oto dowiadujemy się jedynie, że in campo albo umieszczony został „hircum cornutum, in medietate una nigrum, in altera scaccatum" ${ }^{3}$. Przekaz dziejopisa nie daje tym samym podstaw do określenia tynktur szachownicy i nie pozwala stwierdzić, czy kozła przedstawiano wówczas jako zwierzę wspięte, jak na pieczęci Wierusza, czy też kroczące, jakie widnieje w kodeksie arsenalskim, będącym powstałą w XVI wieku, wzbogaconą o barwne rysunki herbów, redakcją Klejnotów Długosza ${ }^{54}$. Zamieszczony w kodeksie tym herb Wieruszów, z kroczącym kozłem, na poły czarnym, na poły szachowanym w czerwone i srebrne cegły, nabrał już wtedy trwałych cech rodzinnego godła, gdyż w identycznej (lub zbliżonej) wersji powielały go odtąd nieodmiennie późniejsze herbarze polskiej szlachty ${ }^{55}$. Niektórzy badacze skłaniają się jednak do wniosku, że takie właśnie godło funkcjonowało co najmniej od końca XIV stulecia ${ }^{56}$. Powołują się przy tym na pieczęć z 1395 roku, należącą do wzmiankowanego już Bernarda Lutoldowica, ojca Wieru-

${ }^{51}$ Wywody szlachectwa $w$ Polsce XIV-XVII w. Wyd. W. Semkowicz. „Rocznik Towarzystwa Heraldycznego we Lwowie" 1911-1912, T. 3, s. 18 (nr 75); MRPS, T. 4/3 S, nr 443. Wpis w Metryce Koronnej został wprawdzie umieszczony pod 1405 r., ale — jak przekonująco wykazał R. Rosin (Dzieje Praszki..., s. 237, przyp. 14) - winien być postdatowany na 1422 r.

52 J. Szymański: Herbarz średniowiecznego rycerstwa..., s. 292.

${ }^{53}$ Insignia seu clenodia Regni Poloniae. Ed. I. Polkowski, Ż. Pauli. In: Joannis Dlugossi senioris canonici cracoviensis Opera Omnia. Ed. A. Przeździecki. Vol. 1. Cracoviae 1887, s. 571; Klejnoty Dtugoszowe. Oprac. i wyd. M. FrIedBerG. „Rocznik Polskiego Towarzystwa Heraldycznego we Lwowie" 1930, T. 10, s. 71.

${ }^{54}$ H. Polaczkówna: Stemmata Polonica, rękopis nr 1114 Klejnotów Dlugosza w Bibliotece Arsenatu w Paryżu. „Prace sekcyi historyi sztuki i kultury Towarzystwa Naukowego we Lwowie” 1927, T. 1, z. 2, s. 214. Opis herbu brzmi tu następująco: „Wierusszowa, quae in albo campo hircum per anteriorem partem nigrum et in posteriori admodum tabule latruncularie depictum gestat".

55 B. PAprocki: Herby rycerstwa polskiego. Wyd. J.K. Turowski. Kraków 1858, s. 675 (kozioł - w połowie czarny, w połowie szachowany, czerwono-srebrny - kroczy w lewą heraldycznie stronę); K. Niesiecki: Herbarz polski. Wyd. J.N. Bobrowicz. T. 9. Lipsk 1842, s. 311; J. Szymański: Nieznane źródto heraldyki polskiej z XVI wieku. St. Źr. 1990, T. 32/33, s. 140 (tutaj kozioł skaczący i w połowie brunatny); TenżE: Herbarz rycerstwa polskiego z XVI wieku. Warszawa 2001, s. 314, 319. Zob. też: L. Wojcıесноwsкi: Ród Wieruszów..., s. 36-37.

56 F. Piekosiński: Heraldyka polska wieków średnich. Kraków 1899, s. 175 (nr 109). 
sza, na której wyobrażono tarczę herbową, na niej zaś — ich zdaniem — herb Wieruszowa, czyli kroczącego w prawa stronę kozła ${ }^{57}$. Pomimo to jako odmianę najtrafniejszą dla Wieruszów publikują herb eksponujący wspiętego kozła, w połowie czarnego, w połowie szachowanego ${ }^{58}$.

Pieczęciami przedstawicieli Wieruszów w okresie kształtowania się rodowego godła familii zainteresował się bliżej Leszek Wojciechowski. Historyk ten, prowadząc badania nad początkami rodu i jego pierwszymi pokoleniami, zinwentaryzował cztery zachowane — jak sądził — stemple z lat 1395-1448, z czego trzy wzmiankowane już dawniej w literaturze (z 1395, 1413 i 1419 roku) oraz jeden wcześniej nienotowany (z 1448 roku $)^{59}$. Dwa z nich należały do Lutolda, syna Bieniasza, piszącego się kolejno z Walichnów, Cieszęcina i Białej (z 1413 i 1448 roku) ${ }^{60}$, natomiast po jednym do znanych nam Bernarda Lutoldowica (z 1395 roku) ${ }^{61}$ i jego syna Wierusza z Kąów (z 1419 roku) ${ }^{62}$. Zestawiony przezeń katalog nie jest kompletny. Należy go uzupełnić jeszcze o trzy nieznane odciski. Najstarszy z nich uwierzytelnia dokument Bernarda z datą 18 stycznia 1397 roku (fot. 3) ${ }^{63}$, którym zatwierdził on sprzedaż Prusicka, wsi leżącej koło Nowej Brzeźnicy w Sieradzkiem, podskarbiemu krakowskiemu Hinczce z Rogowa przez swoich synów Wierusza i Lutolda z Kątów ${ }^{64}$;

${ }^{57}$ I. Zakrzewski, w: KDW, T. 3, s. 642 (nr 1960); A. MaŁecki: Studia heraldyczne. T. 2. Lwów 1890, s. 138; F. Piekosiński: Heraldyka polska..., s. 175 ( $\mathrm{nr}$ 109).

${ }^{58}$ F. Piekosiński: Heraldyka polska..., s. 175 (fig. 291). Zob. też m.in.: S. GórzyŃski, J. Kochanowski: Herbarz szlachty polskiej. Warszawa 1990, s. 160; https://pl.wikipedia.org/ wiki/Wieruszowa\#/media/Plik:POL_COA_Wieruszowa.svg [data dostępu: 25.07.2019].

${ }_{59}$ Archiwum Archidiecezjalne w Gnieźnie (dalej: AAd. Gn.), Dyplomy Gnieźnieńskie (dalej: Dypl. Gn.), nr 251, 349 (pieczęcie z 1395 i 1419 r.); Archiwum Jasnogórskie (dalej: AJG), sygn. D 26 (pieczęć z 1413 r.); AGAD, Zbiór dokumentów pergaminowych (dalej: ZDP), nr 3518 (pieczęć z 1448 r.); L. WoJciechowski: Ród Wieruszów..., s. 37, przyp. 12 i 13.

${ }^{60}$ AJG, sygn. D 26; AGAD, ZDP, nr 3518. Lutold, syn Bieniasza, był bratankiem Bernarda Lutoldowica; miał braci: Bieniasza, Wierusza i Paszka, panów na Niemojewie, Osieku, Białej i Walichnowach, zob. L. Wojciechowski: Ród Wieruszów..., s. 51 i tabl. po s. 54.

${ }^{61}$ AAd. Gn., Dypl. Gn., nr 251.

${ }_{62}$ Tamże, nr 349.

${ }^{63}$ ANKr, Zbiór Rusieckich. Dokumenty pergaminowe (dalej: ZR. Dok. perg.), nr 89. Dokument ten był L. Wojciechowskiemu znany (zob. L. WoJciechowski: Ród Wieruszów..., s. 50, przyp. 98 i s. 51, przyp. 102), a mimo to w zestawionym przez siebie katalogu pieczęci pominął on wiszące przy nim sigillum Bernarda. Co ciekawe, podając informację o sprzedaży wsi Prusicko Hinczce z Rogowa, nie odnotował w przypisie rzeczonego dokumentu, powołując się na opracowanie o charakterze słownikowym (tamże, s. 50 i przyp. 95). O nabywcy Prusicka, rycerzu Hinczce z Roszkowic (i Rogowa), protoplaście Rogowskich, zob. B. CzwojdraK: Rogowscy herbu Działosza podskarbiowie królewscy. Studium $z$ dziejów możnowładztwa $w$ drugiej połowie XIV $i$ w XV wieku. Katowice 2002, s. $36-47$.

${ }^{64}$ W kwestiach genealogicznych zob.: L. Wojciechowski: Ród Wieruszów..., s. 49-50 i tabl. po s. 54; T. Stolarczyк: Szlachta wieluńska..., s. 21-24; J. Sperka: Otoczenie..., s. 191. 
młodszy wisi przy cytowanym wcześniej dokumencie Wierusza z Kątów z 28 stycznia 1426 roku (fot. 1) ${ }^{65}$; najmłodszy zaś, należący do Klemensa Wierusza $\mathrm{z}$ Kątów, pana na Wieruszowie ${ }^{66}$, widnieje na wystawionym przez niego dokumencie z 16 czerwca 1447 roku (fot. 4) ${ }^{67}$. Dwa pierwsze zostały wyciśnięte za pomocą tych samych typariuszy, których ich dysponenci użyli odpowiednio także w 1395 i 1419 roku $^{68}$. Mamy więc do dyspozycji łącznie siedem odcisków stempli, ale stanowi je tylko pięć typów pieczęci, przy czym cztery dokładnie te, które zestawił L. Wojciechowski, i jeden zupełnie dotąd nieznany, należący do czterech Wieruszów. O ile w dawniejszej historiografii na zinwentaryzowanych egzemplarzach dostrzegano, jak już nam wiadomo, herb zwany Wieruszową, a zatem na poły szachowanego, kroczącego bądź wspiętego kozła ${ }^{69}$, o tyle zdaniem L. Wojciechowskiego wyobrażano na nich jelenia ${ }^{70}$. W przekonaniu tym umacniała badacza zapiska z 10 maja 1418 roku, zachowana w aktach konsystorza gnieźnieńskiego, w której odnotowano pieczęć Wierusza z Kątów, starosty wieluńskiego (Veruschius heres in Kanthi capitaneus Welunensis), uwierzytelniającą dokument wystawiony przez niego 26 lutego $1415 \mathrm{roku}$, opisując ją następującymi słowami: ,[...] sigillum rotunde figure in pensula pergamenti de cera, intus de nigra extra de communi, subappendebat, in cuius medio arma signi huiusmodi [w tym miejscu — wedle słów wydawcy

65 AP Wrocław, Rep. 66, nr 463.

${ }^{66}$ Klemens Wierusz, występujący w źródłach w latach 1442-1451, był potomkiem Klemensa ze Świby i Wieruszowa lub Wierusza Bernardowica. W 1442 r., podczas najazdu na ziemię wieluńską wojsk starosty wrocławskiego Leonarda Assenheimera, najemnika w służbie Elżbiety Luksemburskiej, wdowy po Albrechcie Habsburgu i politycznej przeciwniczki Władysława III Warneńczyka, został wzięty do niewoli. W lochu we Wrocławiu, dokąd został wywieziony, spędził blisko 5 lat. Poległ w bitwie pod Byczyną w 1451 r.; zob. o nim m.in.: L. Koczy: Dzieje miasta..., s. 18; L. Wojciechowski: Ród Wieruszów..., s. 52 i tabl. po s. 54; R. Rosin: Dzieje Praszki..., s. 244; T. Stolarczyk: Szlachta wieluńska..., s. 54; T. GrabARCZYK, T. NowAK: Wieluń pod panowaniem pierwszych Jagiellonów (1391-1492). „Rocznik Wieluński” 2007, T. 7, s. 15 i przyp. 44; Ciż: Dzieje polityczne Wielunia (do 1580 roku). W: Wieluń. Monografia miasta. Red. A. Szymczak. T. 1: Wieluń. Dzieje miasta do 1792 roku. Łódź-Wieluń 2011, s. 63 i przyp. 56.

${ }^{67}$ AP Wrocław, Dokumenty miasta Wrocławia (dalej: DmWr.), nr 3241. Ta sama najpewniej pieczęć uwierzytelniała dwa inne wystawione przez Klemensa dokumenty, z 14 czerwca i 17 października 1447 r., ale dziś przy pierwszym zachował się jedynie pergaminowy pasek po pieczęci, przy drugim zaś — nacięcie w pergaminie, zob. AP Wrocław, DmWr., nr 3241 (druga ekspedycja cytowanego wcześniej dokumentu) i 3273.

68 AAd. Gn., Dypl. Gn., nr 251, 349.

69 I. Zakrzewski, w: KDW, T. 3, s. 642 (nr 1960); A. Malecki: Studia heraldyczne..., s. 138; F. Piekosiński: Heraldyka polska..., s. 175 (nr 109 i fig. 291); Tenże, w: KDW, T. 5, s. 291 (nr 309); J. FiJAleK, w: ZDPaul, z. 1, s. 116 (nr 63).

${ }^{70}$ L. Wojciechowski: Ród Wieruszów..., s. 37. Warto dodać, że jelenia na pieczęci Bernarda Lutoldowica z 1397 r. domyślał się także autor inwentarza dokumentów ze Zbioru Rusieckich w Archiwum Narodowym w Krakowie, opisując wyobrażony na niej herb jako Brochwicz II. Swej identyfikacji nie był jednak pewny, gdyż opatrzył ją znakiem zapytania. 
źródła - pisarz wyrysował hełm z pióropuszem] videlicet galea cum tribus pennis strutionum dicta galee suprapositis, sub qua galea clipeus, in quo clipeo cervus erectis cornibus capitis apparebat, littere vero circumferencialiter hec: Weruschy de Kanthi — inter duas lineas legebantur" "71. Wydaje się jednak, że lubelski historyk przecenił wiarygodność owej zapiski, nadmiernie ufając umiejętnościom, jakie w zakresie napieczętnej epigrafiki i ikonografii przejawiał jej autor. Nie mogło być zresztą inaczej, skoro znał jedynie pieczęć, którą Wierusz przywiesił do dokumentu z 4 grudnia 1419 roku, ta zaś - wbrew jego twierdzeniu, że jest „dobrze zachowana” — przetrwała w stanie udaremniającym próbę weryfikacji cytowanego przekazu ${ }^{72}$. Widać na niej wprawdzie bardzo wyraźnie wydłużoną wertykalnie rozetę o czterech płatkach, w którą wpisano pochyloną w lewo tarczę herbową z godłem, przykrytą hełmem rycerskim typu ,żabi pysk”, ozdobionym klejnotem z piór, ale zatarcia na powierzchni stempla oraz zniekształcenia odcisku na skutek niedokładnego przyłożenia tłoka do woskowej masy (zauważalne jest przede wszystkim odchylenie kształtu prawego heraldycznie łuku rozety, który poszerza się niesymetrycznie ku skrajowi pieczęci) uniemożliwiają rozpoznanie szczegółów wizerunku. Trudno choćby rozszyfrować niewyraźny klejnot zdobiący hełm. Na tarczy dostrzec można wspięte w lewą stronę zwierzę z długimi rogami, jednak nie sposób stwierdzić, czy chodzi o jelenia, czy o kozła. Nieczytelna jest też legenda, $\mathrm{z}$ całkowicie zniszczonym (może nawet $\mathrm{w}$ ogóle nieodciśniętym?) eksplicitem i niewyraźnymi reliktami liter w incipicie. Zarówno godło, jak i napis udaje się jednoznacznie zidentyfikować na podstawie nieznanej badaczowi, wyciśniętej za pomocą tego samego tłoka, pieczęci Wierusza uwierzytelniającej wspomniany wcześniej dokument kończący spór między braćmi Janem i Michałem, synami Andrzeja Zmarzlika, a konwentem szpitala św. Macieja we Wrocławiu z 1426 roku $^{73}$. Eksponuje ona, jak nam już wiadomo, wspiętego w lewą stronę kozła, na co jednoznacznie wskazuje kształt i sposób stylizacji rogów, a napis otokowy, nieznacznie zatarty, głosi: WERISON[E] / VON KANT. I jedno, i drugie odbiega więc od opisu pieczęci przywieszonej do dokumentu z 1415 roku, co oznacza, że mielibyśmy do czynienia albo z dwoma różnymi typami sigillów, albo z niedostatecznie wyraźnym odciskiem tego samego stempla, a w efekcie błędną identyfikacją jego godła i niepoprawnym odczytem legendy przez autora deskrypcji. Z obu supozycji bardziej wiarygodna wydaje się ta druga. Trudno bowiem zakładać, by w okresie ścisłego zespalania z Królestwem Polskim ziemi wieluńskiej, dotychczas integralnie związanej jako lenno z księstwem Władysława Opolczyka ${ }^{74}$, łacińską wersję inskrypcji występującej

${ }^{71}$ ACI, T. 2, s. 39 (nr 119); L. Wojciechowski: Ród Wieruszów..., s. 37.

72 AAd. Gn., Dypl. Gn., nr 349.

73 AP Wrocław, Rep. 66, nr 463.

${ }^{74}$ W. Szczygielski: Dzieje ziemi..., s. 14-16; T. Olejnik: Wieluń pod władztwem Władysława Opolczyka. „Rocznik Wieluński” 2006, T. 6, s. 7-16; M. Antoniewicz: Podstawy 
na pieczęci z 1415 roku, zapisanej prawdopodobnie minuskułą (Weruschy de Kanthi), wyparł niemieckojęzyczny napis ryty literami majuskuły gotyckiej. Naturalna ewolucja - tak epigraficzna, jak i językowa - napisu napieczętnego przebiegać wszak powinna $\mathrm{w}$ odwrotnym kierunku ${ }^{75}$. Należy też zauważyć, że wspomniany w 1418 roku Wierusz z Kątów cztery lata później rozsądzał w Wieluniu jako sędzia ziemi wieluńskiej (Wyeruslaus de Kanti iudex terrae Wyelunensis) sprawę o oczyszczenie szlachectwa, w której świadkami byli jego krewni: Lutold z Cieszęcina i Bernard z Olewina, obaj herbu Wieruszowa (de clenodio Wyeruschowye) ${ }^{76}$, przedstawiającego — jak wiadomo - kozła.

Wartość źródłowa odnalezionego zabytku z kolekcji dokumentów przechowywanych we wrocławskim archiwum unaocznia się w jeszcze jednym aspekcie. Oto przynosi on jedyny pełny i wyraźny wizerunek najstarszego klejnotu rycerskiego herbu Wierusz (Wieruszowa), co jest o tyle istotne, że w historiografii notowano dotąd jedynie jego nowożytną postać, tj. pięć strusich piór ${ }^{77}$, natomiast klejnot średniowieczny albo nie był w ogóle znany ${ }^{78}$, albo na podstawie starszego, zachowanego w gorszej kondycji, odcisku tego samego stempla identyfikowano go, być może per analogiam do nowożytnej formy, ze strusimi piórami ${ }^{79}$. Tymczasem na podstawie pieczęci z 1426 roku wiadomo, że klejnot Wieruszów przedstawiał kitę z piór, która przypominała swą stylizacją cymer herbu Wezemborgów ${ }^{80}$.

Wracając do wątku jelenia, trzeba stwierdzić, że obecności tego zwierzęcia nie można być także pewnym, wbrew temu, co twierdził przywoływany badacz, na pozostałych pieczęciach należących do przedstawicieli Wieruszów. Najstarsze z nich, których dysponentem był Bernard Lutoldowic, a pochodzące z lat 1395-1397, wyobrażają tarczę herbową, na niej zaś rogate, czworonożne zwierzę zwrócone $\mathrm{w}$ prawą (heraldycznie) stronę; $\mathrm{w}$ otoku biegnie napis: S' BERNHARDI WERVSCNO ${ }^{81}$. Choć pieczęć z 1395 roku zachowa-

i zakres władzy księcia Władystawa II opolskiego w ziemi wieluńskiej oraz pólnocno-zachodniej Małopolsce. W: Ksiązę Władysław Opolczyk. Fundator klasztoru Paulinów na Jasnej Górze w Częstochowie. Red. M. Antoniewicz, J. ZBudnieweK. Warszawa 2007, s. 195-246; T. Grabarczyk, T. Nowak: Wieluń pod panowaniem..., s. 5-24; Ciż: Dzieje polityczne Wielunia..., s. 51-80 (zwłaszcza s. 54-57).

${ }^{75}$ Należy dodać, że pieczęć Wierusza z Kątów (Werusschius de Kanthy), dziś niezachowana, ale bez wątpienia tożsama ze znanymi sigillami z lat 1415/1419-1426, uwierzytelniała też dokument z 18 stycznia 1415 r., zob. ANKr, ZR. Dok. perg., nr 104.

${ }^{76}$ Zob. przyp. 51 oraz L. Koczy: Dzieje miasta..., s. 16; R. Rosin: Dzieje Praszki..., s. 237.

77 J. Szymański: Herbarz rycerstwa polskiego..., s. 314, 319.

78 Zob. np. F. Pı́коsı́́ski: Heraldyka polska..., s. 175 (nr 109) — badacz stwierdził, że „klejnot średniowieczny tego herbu nie jest znany”.

${ }^{79}$ L. Wojciechowski: Ród Wieruszów..., s. 37, przy czym informację, że chodzi konkretnie o pióra strusie, opatrzył autor znakiem zapytania.

80 J. Szymański: Herbarz średniowiecznego rycerstwa..., s. 287-288.

81 AAd. Gn., Dypl. Gn., nr 251; ANKr, ZR. Dok. perg., nr 89. 
ła się w zdecydowanie lepszym stanie od pomijanego dotychczas w historiografii — być może ze względu na zatartą powierzchnię odcisku i całkowicie nieczytelną legendę — tożsamego sigillum z 1397 roku, to jednak szczegóły przedstawionego na niej wizerunku, będącego podstawą do identyfikacji godła familii Wieruszów ${ }^{82}$, budzą poważne wątpliwości. Od czoła tarczy widnieją wszak nieregularne zgrubienia wosku, zlewające się z eksponowanymi w tym miejscu rogami zwierzęcia, w których w zależności od kąta padania światła upatrywać można zarówno jeleniego poroża, jak i kozich rogów. Z tego samego powodu dyskusyjne w swej wymowie jest również godło kładzione na tarczy wyobrażonej na herbowych pieczęciach Lutolda, syna Bieniasza, znanych z 1413 i 1448 roku (fot. 5) ${ }^{83}$. Mają one nie tylko częściowo zniekształcone i zatarte powierzchnie odcisków, utrudniające jednoznaczną identyfikację rogów, ale są dodatkowo obłamane i miejscami wykruszone. Napisu otokowego na młodszym egzemplarzu nie sposób już dziś w ogóle odczytać, natomiast jego fragment zachowany na starszym brzmi: + S: LVTOLDI [...]IN ${ }^{84}$.

Pomimo trudności z właściwym określeniem gatunku zwierzęcia pojawiającego się w najstarszej sfragistyce Wieruszów forma stylizacji rogów na najbardziej czytelnych pod tym kątem sigillach Bernarda z 1397 roku (fot. 3) oraz Wierusza z 1426 roku (fot. 1) przekonuje, że w charakterze ich rodzinnego godła występował - zgodnie z przekazem historiograficznej tradycji - kroczący lub wspięty kozioł. Niezbitego dowodu dostarcza nieznana badaczom pieczęć z 1447 roku, w niniejszych rozważaniach jedynie zasygnalizowana i świadomie dotąd pomijana, należąca do Klemensa Wierusza z Kątów (fot. 4) ${ }^{85}$. Stan jej zachowania nie jest, podobnie jak pozostałych, najlepszy, albowiem z legendy, rytej literami minuskuły gotyckiej, udaje się dziś odczytać — bez obawy popełnienia błędu — zaledwie fragment w brzmieniu: + s clem[...] von werusch, ale sam wizerunek napieczętny jest nadspodziewanie wyraźny. Przedstawia on tarczę gotycką typu hiszpańskiego, a na niej czworonożne zwierzę rogate kroczące w prawą heraldycznie stronę. Kształt i sposób wyprofilowania rogów, pozbawionych charakterystycznych dla jeleniego poroża rosoch, nie pozostawiają wątpliwości, że mamy tu do czynienia z ekspozycją kozła. To, że był on stale obecny w heraldyce Wieruszów, a wszelkie próby zastępowania go przez badaczy jeleniem wynikają z niejednoznacznych w swej wymowie najstarszych wizerunków napieczętnych, zdaje się ostatecznie potwierdzać herb Wieruszowa widniejący na odnalezionej, omówionej wcześniej pieczęci miejskiej z 1426 roku (fot. 2).

${ }^{82}$ L. Wojciechowski: Ród Wieruszów..., s. 37, przyp. 12.

${ }^{83}$ AJG, sygn. D 26; AGAD, ZDP, nr 3518.

${ }^{84}$ ZDPaul, z. 1, s. 116 (interesujący nas herb nazwany został tutaj Wieruszową, zatem zwierzę wyobrażone na tarczy identyfikowano z kozłem); L. WoJcıechowski: Ród Wieruszów..., s. 37, przyp. 12.

${ }^{85}$ Zob. przyp. 66 i 67. 
W historiografii wielokrotnie podkreślano ścisły związek między lokacją miasta na prawie niemieckim a powstaniem pieczęci samorządu miejskiego jako instrumentu sprawowania władzy przez radę miejską i stojącego na jej czele burmistrza. Zwracano przy tym uwagę na fakt, że podstawową funkcją pieczęci municypalnej było uwierzytelnianie własnej produkcji kancelaryjnej, a eksponowany na sigillum znak, przyjmujący postać godła lub herbu, służył nie tylko do manifestacji niezbywalnych praw własnościowych i uprawnień sądowych jego dysponenta, ale także do łatwego rozpoznania go $^{86}$. Toteż w przypadku miast prywatnych, do których — jak już nam wiadomo - zaliczał się również Wieruszów, kreacja miejskiego herbu dokonywała się najczęściej albo przez powtórzenie pełnego herbu pana miasta, albo przez jego zmodyfikowanie, albo wreszcie przez wyobrażenie jedynie jego części, przy czym dwa ostatnie rozwiązania ikonograficzne wymusiła praktyka nakazująca odróżniać herb miasta od herbu jego właściciela ${ }^{87}$. W pełni uzasadnione wydaje się $\mathrm{w}$ tym kontekście przekonanie, że pieczętowanie się przez rodzinę Wieruszów jeleniem, jak twierdzi L. Wojciechowski, znalazłoby niechybnie odzwierciedlenie w heraldyce należącego do nich miasta ${ }^{88}$. Tymczasem na odnalezionej pieczęci Wieruszowa, pochodzącej z tego samego okresu, co najstarsze sigilla przedstawicieli familii, zamiast jelenia widnieje kozioł, oddany wprawdzie w niezbyt udanej stylizacji plastycznej, jednak z wyraźnie zaznaczonymi rogami o charakterystycznym dla tego zwierzęcia kształcie. Fakt ten jednoznacznie przekonuje, że Wierusze w charakterze rodzinnego godła używali konsekwentnie wizerunku kozła, choć o nieustabilizowanym układzie, tj. kroczącego lub wspiętego ${ }^{89}$.

${ }^{86}$ J. SZYMański: W sprawie genezy polskich herbów miejskich. W: Spoleczeństwo Polski średniowiecznej. Zbiór studiów. Red. S.K. KuczyŃsKi. T. 6. Warszawa 1994, s. 169-179; M. Adamczewski: Pieczęcie urzędowe..., s. 5-12. O funkcjach herbów miast wielkopolskich, w tym identyfikacyjnej i prawno-ustrojowej, pisał obszernie TenżE: Heraldyka miast..., s. $284-300$.

${ }^{87}$ J. Szymański: $W$ sprawie genezy..., s. 192. Liczne przykłady tego typu kreacji herbów miast prywatnych na ziemiach polskich zestawiają m.in.: W. STRzyżewski: Herby rycerskie $w$ godtach herbów miast ślaskich, pomorskich i nowomarchijskich. W: Etos rycerski w Europie Środkowej $i$ Wschodniej od X do XV wieku. Red. W. PeltZ, J. Dudek. Zielona Góra 1997, s. 137-144; W. Strzyżewski: Treści symboliczne..., s. 80-89; M. AdamcZewski: Heraldyka miast..., s. 156-192; H. SERoKa: Herby miast..., s. 182-228.

${ }^{88} \mathrm{Z}$ praktyką tą spotkaliśmy się już przecież w dobrze rozpoznanych w historiografii, aczkolwiek pochodzących dopiero z czasów nowożytnych, herbach Lututowa, Praszki, a także samego Wieruszowa. We wszystkich powielono wówczas mniej lub bardziej odmieniony motyw kozła eksponowanego w herbie Wieruszów; zob. przyp. 17, 18 i 27.

89 J. Szymański: Herbarz rycerstwa polskiego..., s. 314, 319. Warto w tym miejscu przypomnieć, że symbolika nawiązująca do założycieli i pierwszych właścicieli Wieruszowa utrzymana została również na późniejszych pieczęciach miasta, pomimo przejęcia go w XV w. przez przedstawicieli rodzin rycerskich pieczętujących się herbami Niesobia, Sulima i Łodzia (L. Koczy: Dzieje miasta..., s. 20 - 30; T. Jurek: Krag rodzinny..., s. 31-32). Fakt to o tyle istotny, że zmiana właściciela miasta pociągała za sobą modyfikacje lub całkowitą wymianę 
Pozwala też wskazać terminus ante quem pojawienia się tego motywu w ich herbie.

Przypomnijmy, że interesujące nas tutaj sigillum Wieruszowa wisi na pergaminowym pasku przy dokumencie wystawionym przez Wierusza z Kątów i radę miasta (burmistrza i rajców). Stanowi więc namacalny dowód na to, że u progu XV stulecia w mieście funkcjonowały organy władzy samorządowej wykonujące przysługujące im prerogatywy administracyjne i sądowe, w tym wytwarzanie dokumentacji prawnej ${ }^{90}$. Pieczęcią służącą do jej uwierzytelniania, choć znaną dopiero z 1426 roku, w praktyce kancelaryjnej posługiwano się bez wątpienia już w XIV wieku. W jej legendzie zastosowano wszak majuskułę gotycką z elementami uncjały, która — jak wynika z badań Barbary Trelińskiej — w polskim piśmiennictwie epigraficznym pojawiła się u schyłku XIII, a zanikła w latach 80 . XIV wieku ${ }^{91}$. Lata 80. XIV stulecia można byłoby więc uznać za końcową cezurę powstania zabytku, gdyby nie to, że w napisach otokowych na pieczęciach, zwłaszcza tych o charakterze ogólnomiejskim, taką formę pisma spotykamy także później ${ }^{92}$. Stąd też za jedyny pewny termin ad quem powstania pieczęci należy przyjąć datę wystawienia uwierzytelnionego nią dokumentu, natomiast za moment początkowy uznać lokację miasta, do której doszło najpóźniej — o czym była mowa — w 1368 roku, kiedy to Wieruszów po raz pierwszy wymieniono w źródłach jako oppidum ${ }^{93}$. Tym samym na czas poprzedzający tak zakreśloną chronologię sporządzenia tłoka najstarszej pieczęci Wieruszowa wypada datować początki herbu założycieli i pierwszych posesorów miasta, z kozłem jako ich rodzinnym godłem.

Kozioł, genetycznie związany z godłem rycerskiej familii Wieruszów, jest jednym z dwóch elementów składających się na pełne wyobrażenie najstarszego herbu Wieruszowa. Drugim z nich jest szachownica, która kieruje naszą uwage po raz kolejny w stronę herbu właścicieli miasta, eksponującego — jak wiadomo - kozła na poły czarnego, na poły szachowanego w cegły czerwone i srebrne ${ }^{94}$. Mamy więc tu do czynienia $\mathrm{z}$ nietypowym odmienieniem rodowego godła, polegającym na umieszczeniu charakterystycznych ikonogra-

jego dotychczasowego herbu, przy czym należy zaznaczyć, że ani na Śląsku, ani na ziemiach Korony nie było to zjawisko powszechne, zob. W. STRzYżEwski: Treści symboliczne..., s. 8687; H. SeroKa: Herby miast..., s. 225-228.

${ }^{90}$ Dziejów samorządu miejskiego Wieruszowa w okresie średniowiecza nie sposób dokładniej prześledzić ze względu na szczupłość materiału źródłowego. Już pod koniec lat 20. XX w. ubolewano, że najstarsze księgi miejskie Wieruszowa, pozwalające wniknąć głębiej w zagadnienia ustrojowe i wewnętrzne sprawy miasta, zachowały się dopiero od XVI w., zob. L. Koczy: Dzieje miasta..., s. 1-2, 7-9.

${ }_{91}$ M. Haisig: Studia nad legenda..., s. 75; B. TrelińsKa: Gotyckie pismo epigraficzne w Polsce. Lublin 1991, s. 15, 28-29.

${ }_{92}$ M. HAIsIG: Studia nad legenda..., s. 75.

93 Zob. przyp. 6.

94 J. SZYMaŃSki: Herbarz średniowiecznego rycerstwa..., s. 292. 
ficznie jego części składowych jako osobnych elementów na dzielonej w słup tarczy herbowej. Lewe jej pole zajął połukozioł, prawe zaś wypełniła w całości szachownica. Wprawdzie na żadnej z omówionych pieczęci należących do przedstawicieli Wieruszów nie widać na koźle ani szachownicy, ani nawet linii wyznaczającej podział zwierzęcia na dwie części, ale ich brak tłumaczyć można całkowitym zatarciem. Trudno bowiem zakładać, by szachownica w herbie Wieruszowa poprzedziła moment pojawienia się szachowanego kozła w herbie rodowym Wieruszów.

Nie znamy barw najstarszego herbu Wieruszowa, ale jego ścisły związek z herbem założycieli i właścicieli miasta nie pozostawia wątpliwości, że prawe pole dzielonej w słup tarczy wypełniała szachownica czerwono-srebrna, a na srebrnym polu lewym widniał czarny połukozioł (fot. 6).

Odnalezienie nieznanej dotychczas czternastowiecznej pieczęci Wieruszowa pozwala nie tylko uściślić informacje na temat początków herbu familii Wieruszów, zwłaszcza jego treści, formy i kształtu, ale także zrewidować ustalenia badaczy odnośnie do najstarszej heraldyki miasta. Przede wszystkim należy odrzucić wniosek, że Wieruszów pieczętował się jedynie herbem wyobrażającym czarnego kozła dźwigającego na grzbiecie czerwoną fasadę kościoła $\mathrm{z}$ dwiema wieżami, jaki widnieje na zachowanych sigillach miejskich pochodzących dopiero z XVIII wieku. Choć istnieją przesłanki świadczące o tym, że miasto posługiwało się takim właśnie herbem już u progu XVI stulecia, to nie znajduje uzasadnienia teza, jakoby funkcjonował on w przestrzeni miejskiej już od XV wieku, występując rzekomo na najstarszej pieczęci miejskiej, której istnienia tylko się domyślano, powstałej rzekomo w latach 1401—1467, tj. po fundacji paulińskiego kościoła pw. Ducha Świętego, dokonanej przez Bernarda Wierusza oraz jego syna, a przed wyjściem Wieruszowa z rąk jego dotychczasowych właścicieli. Fakt, iż za pomocą czternastowiecznej (pierwszej) pieczęci uwierzytelniano miejskie dokumenty jeszcze w latach 20 . XV wieku, świadczy dowodnie o tym, że sprowadzenie paulinów do Wieruszowa, będące bez wątpienia wydarzeniem wielkiej wagi w dziejach samego miasta, dla rozwoju jego heraldyki nie stanowiło wówczas cezury o fundamentalnym znaczeniu. Był nią natomiast pożar, jaki wybuchł w mieście w 1497 lub 1498 roku. Żywioł spowodował wszak tak wielkie zniszczenia, że ówczesny dziedzic Wieruszowa Andrzej Wierzbięta Wieruszowski alias Baranowski herbu Niesobia, przypuszczalnie w obawie przed jego wyludnieniem, nadał w 1498 roku mieszczanom Memoriale libertatis sive cognitio privilegii, będące swoistym odnowieniem aktu lokacyjnego zatwierdzającym wszystkie dotychczasowe przywileje miasta oraz regulującym szczegółowo jego ustrój ${ }^{95}$. W pożodze uległ także zniszczeniu dotychczas używany tłok pieczęci miejskiej, skoro

${ }_{95}$ L. Koczy: Dzieje miasta..., s. 7-9. O wystawcy przywileju zob. T. Jurek: Krag rodzinny..., s. 32-33 i tabl. 5 (s. 30); T. StolarczYк: Szlachta wieluńska..., s. 57. 
już na początku XVI wieku zastąpiono go nowym. W tym pierwszym widzieć należy bezspornie czternastowieczne jeszcze sigillum Wieruszowa, ponieważ brak dowodów na jego wymianę po 1426 roku. Dopiero na przełom XV i XVI wieku datować zatem można, wbrew stanowisku historyków, powstanie typariusza $\mathrm{z}$ najstarszym wizerunkiem odmienionego herbu miasta, uaktualniającego treść ikonograficznego przekazu poprzez połączenie symboliki z jednej strony odwołującej się bezpośrednio do założycieli miasta i reprezentującej zwierzchność feudalną (kozioł), z drugiej zaś będącej formą manifestacji miejskiej samodzielności (fasada kościoła z dwiema wieżami).

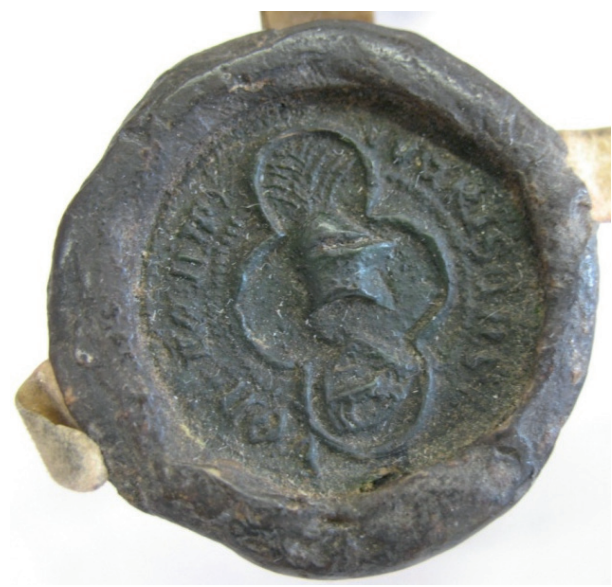

Fot. 1. Pieczęć Wierusza z Wieruszowa i Kątów, 1426 r.

AP Wrocław, Rep. 66, nr 463

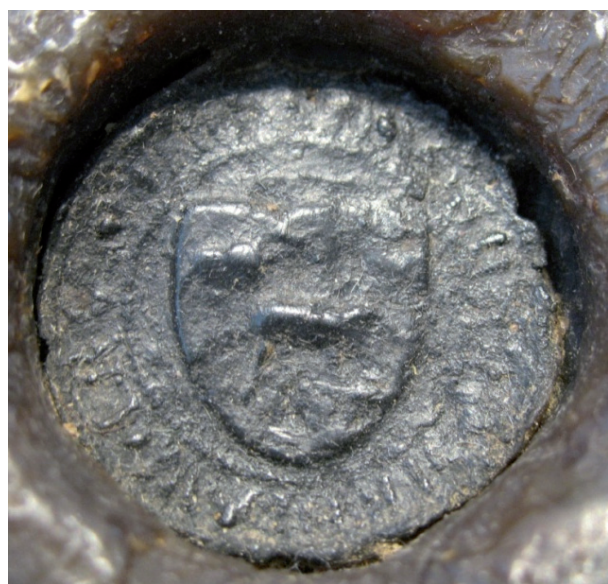

Fot. 3. Pieczęć Bernarda, syna Lutolda, 1397 r. ANKr, ZR. Dok. perg., nr 89

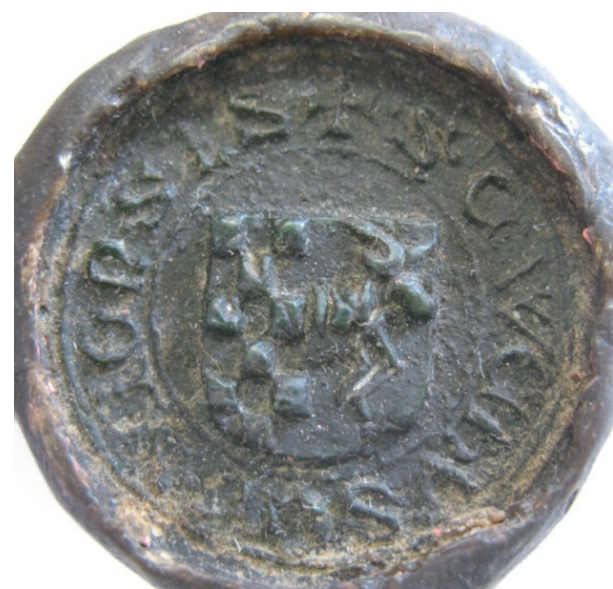

Fot. 2. Pieczęć miasta Wieruszowa, $1426 \mathrm{r}$. AP Wrocław, Rep. 66, nr 463

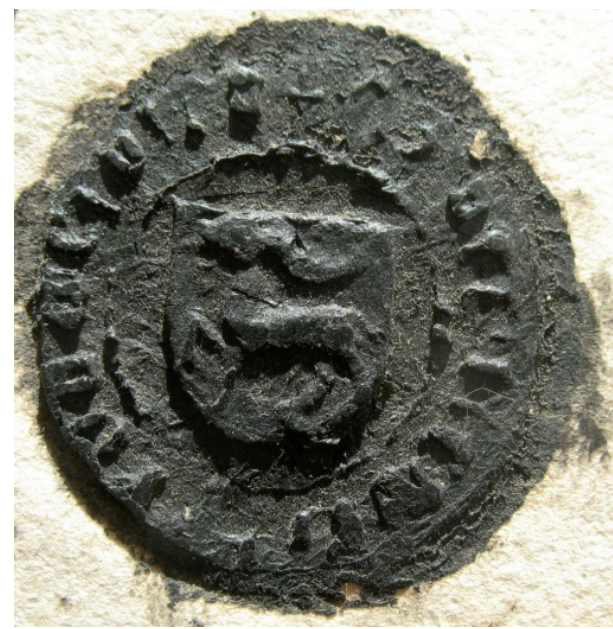

Fot. 4. Pieczęć Klemensa Wierusza, 1447 r. AP Wrocław, DmWr., nr 3241 


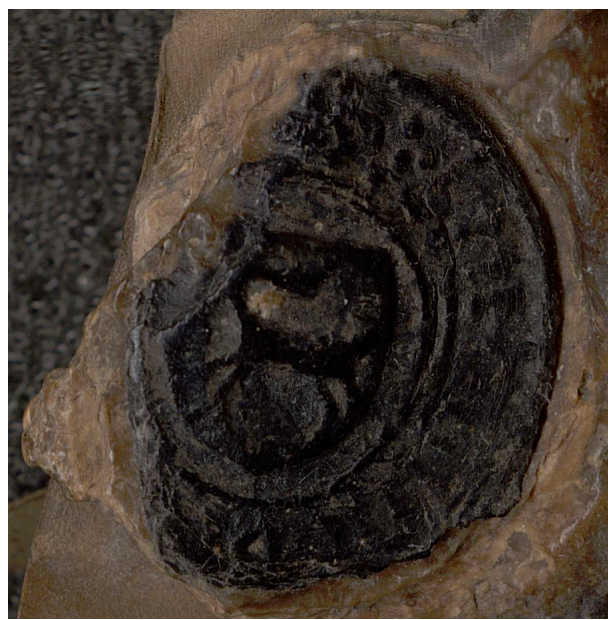

Fot. 5. Pieczęć Lutolda, syna Bieniasza, $1448 \mathrm{r}$.

AGAD, ZDP, nr 3518

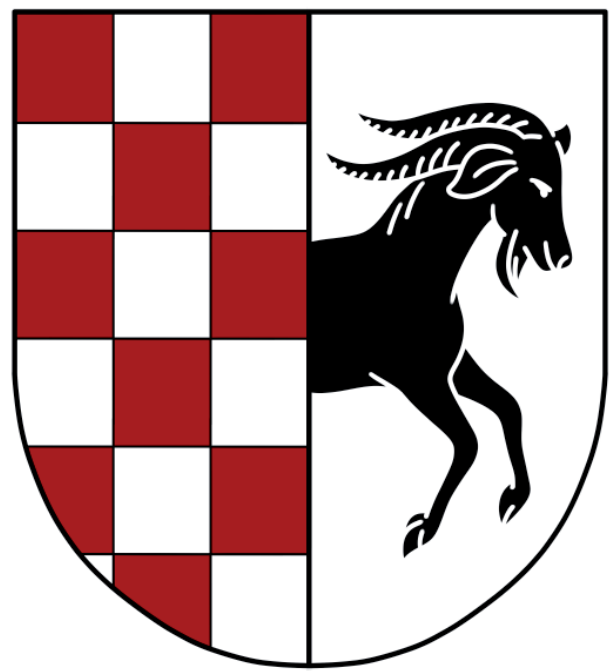

Fot. 6. Czternastowieczny herb Wieruszowa, rekonstrukcja (oprac. graficzne Wiktoria Wójcik)

\section{Bibliografia}

\section{Źródła rękopiśmienne}

Archiwum Archidiecezjalne w Gnieźnie: Dyplomy Gnieźnieńskie, nr 251, 349.

Archiwum Główne Akt Dawnych w Warszawie: Zbiór dokumentów pergaminowych, nr 3518. Archiwum Jasnogórskie, sygn. D 26.

Archiwum Narodowe w Krakowie: Zbiór Rusieckich. Dokumenty pergaminowe, nr 89, 104.

Archiwum Państwowe we Wrocławiu: Dokumenty miasta Wrocławia, nr 3241, 3273; Rep. 66, $\mathrm{nr}$ 463; Rep. 66: Inhaltsverzeichniß der Urkunden des ehemaligen Mathias-Stifftes zu Breslau. 1. Theil: $1252-1500$ (rps).

\section{Źródla drukowane}

Acta capitulorum nec non iudiciorum ecclesiasticorum selecta. Wyd. B. UlanowsKi. T. 2: Acta iudiciorum ecclesiasticorum dioecesum Gneznensis et Poznaniensis (1403-1530). Kraków 1902. 
Insignia seu clenodia Regni Poloniae. Ed. I. Polkowski, Ż. Pauli. In: Joannis Dlugossi senioris canonici cracoviensis Opera Omnia. Ed. A. PrzeźDziecki. Vol. 1. Cracoviae 1887.

Klejnoty Dlugoszowe. Oprac. i wyd. M. FriedBerg. „Rocznik Polskiego Towarzystwa Heraldycznego we Lwowie" 1930, T. 10.

Kodeks dyplomatyczny Wielkopolski. T. 2-3. Wyd. I. ZaKrZewski. Poznań 1878-1879; T. 5. Wyd. F. Piekosiński. Poznań 1908.

Landbuch księstw świdnickiego i jaworskiego. Wyd. T. JUREK. T. 1: 1366-1376. Poznań 2004; T. 2: 1385-1395. Poznań 2000.

Liber fundationis episcopatus Vratislaviensis. Hrsg. H. Markgraf, J.W. Schulte. In: Codex diplomaticus Silesiae. Bd. 14. Breslau 1889.

Matricularum Regni Poloniae Summaria. Ed. T. Wierzbowski. Pars IV: Sigismundi I regis tempora complectens (1507-1548). Vol. 3: Acta vicecancellariorum, 1533-1548. Varsoviae 1905.

Niesiecki K.: Herbarz polski. Wyd. J.N. Bobrowicz. T. 9. Lipsk 1842.

PAProcki B.: Herby rycerstwa polskiego. Wyd. J.K. TurowsKi. Kraków 1858.

Patykiewicz W.: Materiały do dziejów terenów diecezji częstochowskiej. Archidiakonat wieluński. „Częstochowskie Wiadomości Diecezjalne” 1958, T. 32.

Polaczkówna H.: Stemmata Polonica, rękopis nr 1114 Klejnotów Dlugosza w Bibliotece Arsenału w Paryżu. „Prace sekcyi historyi sztuki i kultury Towarzystwa Naukowego we Lwowie" 1927, T. 1, z. 2.

Urkunden des Klosters Kamenz. Hrsg. P. Pfotenhauer. In: Codex diplomaticus Silesiae. Bd. 10. Breslau 1881.

Wywody szlachectwa w Polsce XIV-XVII w. Wyd. W. Semkowicz. „Rocznik Towarzystwa Heraldycznego we Lwowie" 1911-1912, T. 3.

Zarzadzenie Ministra Spraw Wewnętrznych z dnia 18 czerwca 1937 r. w sprawie zatwierdzenia herbu miasta Wieruszowa. „Monitor Polski”, R. 20, nr 164, poz. 274 z 21 lipca 1937 r.

Zbiór dokumentów Zakonu OO. Paulinów w Polsce. Oprac. J. FiJaŁeK. Z. 1: (1328-1464). Kraków 1938.

ZвudnieweK J.: Kopiarz dokumentów konwentu Paulinów w Wieruszowie. Cz. 2: Treść dokumentów kopiarza. „Archiwa, Biblioteki i Muzea Kościelne” 1973, T. 27.

\section{Opracowania}

AdamcZewski M.: Heraldyka miast wielkopolskich do końca XVIII w. Warszawa 2000.

Adamczewski M.: Herb i pieczęcie miasta. W: Nad górna Prosną. Monografia Praszki. Red. T. KRZEMIŃSKi. Łódź 1999.

Adamczewski M.: Miejsce „Albumu Herbów Miast Królestwa Polskiego” z 1847 r. w polskiej heraldyce miejskiej. W: Herby miast polskich w okresie zaborów (1772-1918). Materiaty z sesji naukowej, Włocławek 5-6 grudnia 1996 r. Red. S.K. KucZYŃSKI. Włocławek 1999.

Adamczewski M.: Pieczęcie urzędowe władz lokalnych z obszaru Polski centralnej. Cz. 3: Pieczęcie władz miejskich do 1950 roku. Zgierz 2010.

Antoniewicz M.: Herby miast województwa częstochowskiego. Częstochowa 1984.

Antoniewicz M.: Podstawy i zakres władzy księcia Władysława II opolskiego w ziemi wieluńskiej oraz pótnocno-zachodniej Małopolsce. W: Książe Władysław Opolczyk. Fundator 
klasztoru Paulinów na Jasnej Górze w Częstochowie. Red. M. Antoniewicz, J. ZbudnieWEK. Warszawa 2007.

Bogucka M., Samsonowicz H.: Dzieje miast i mieszczaństwa w Polsce przedrozbiorowej. Wrocław 1986.

Сноміскі A.: Herby miast i ziem polskich. Warszawa 1939.

Czwojdrak B.: Rogowscy herbu Działosza podskarbiowie królewscy. Studium z dziejów możnowladztwa w drugiej połowie XIV i w XV wieku. Katowice 2002.

Drelicharz W., Piech Z.: Dawne $i$ nowe herby Małopolski. Oprac. graficzne B. Wideak. Kraków 2004.

GoŁdYn P.: Symbolika religijna i kościelna w herbach miast polskich do końca XX wieku. Warszawa 2008.

GóRZYŃSKi S., KochanowsKi J.: Herbarz szlachty polskiej. Warszawa 1990.

Grabarczyk T., Nowak T.: Dzieje Lututowa do połowy XVI wieku. W: Sześć wieków Lututowa. Studia i materiaty. Red. T. OlejniK. Wieluń 2007.

Grabarczyk T., Nowak T.: Dzieje polityczne Wielunia (do 1580 roku). W: Wieluń. Monografia miasta. Red. A. Szymczak. T. 1: Wieluń. Dzieje miasta do 1792 roku. Łódź-Wieluń 2011.

Grabarczyk T., NowaK T.: Wieluń pod panowaniem pierwszych Jagiellonów (1391-1492). „Rocznik Wieluński” 2007, T. 7.

Gumowski M.: Herby miast polskich. Warszawa 1960.

Haisig M.: Osiagnięcia i postulaty w zakresie sfragistyki polskiej. „Studia Źródłoznawcze” 1959, T. 4.

HaISIG M.: Sfragistyka i heraldyka miast polskich w świetle dotychczasowych badań. „Nauka i Sztuka" 1947, R. 6.

Haisig M.: Studia nad legenda pieczęci miejskiej. Wrocław 1953.

JUREK T.: Krag rodzinny starosty wielkopolskiego Wierzbięty (1352-1369), czyli początki rodu Niesobiów. „Genealogia. Studia i Materiały Historyczne” 1991, T. 1.

Kaganiec M.: Herby miast województwa śląkiego. Katowice 2007.

Kobierzycki J.: Przyczynki do dziejów ziemi sieradzkiej. Warszawa 1915.

Koczy L.: Dzieje miasta Wieruszowa. Poznań 1930.

Kozierowski S.: Obce rycerstwo w Wielkopolsce w XIII—XVI wieku. Poznań 1929.

KUCZYŃSKI S.K.: Osiagnięcia i postulaty $w$ zakresie heraldyki polskiej. W: Tradycje i perspektywy nauk pomocniczych historii w Polsce. Materiaty z sympozjum w Uniwersytecie Jagiellońskim dnia 21-22 października 1993 roku profesorowi Zbigniewowi Perzanowskiemu przypisane. Red. M. RoKosz. Kraków 1995.

KUCZYŃski S.K.: Polonika heraldyczne i sfragistyczne w zbiorach leningradzkich. „Archeion” 1978, T. 66.

KuCZyŃSki S.K., PudŁowski L.: Udziat archiwów państwowych w tworzeniu herbów okresu międzywojennego. „Archeion” 1987, T. 82.

KwiateK J., LiJewsKi T.: Leksykon miast polskich. Warszawa 1998.

MaŁecki A.: Studia heraldyczne. T. 2. Lwów 1890.

Miasta polskie w Tysiacleciu. T. 2. Wrocław-Warszawa-Kraków 1967.

NowaK T.: Własność szlachecka w ziemi wieluńskiej na początku 2. połowy XV wieku. „Rocznik Łódzki” 2014, R. 61.

OlejNiK T.: Pieczęcie i herby miast ziemi wieluńskiej. Łódź 1971.

Olejnik T.: Wieluń pod władztwem Władysława Opolczyka. „Rocznik Wieluński” 2006, T. 6.

PiekosińsKi F.: Heraldyka polska wieków średnich. Kraków 1899.

Plewako A., Wanag J.: Herbarz miast polskich. Warszawa 1994.

Polskie herby miejskie. Red. T. Szczechura. Oprac. graficzne R. Sidorowski. Warszawa 1953. 
Rosin R.: Dzieje Praszki do początku XIX wieku. W: Nad górna Prosna. Monografia Praszki. Red. T. KRZEMIŃsKi. Łódź 1999.

Rosin R.: Ziemia wieluńska w XII-XVI w. Studia z dziejów osadnictwa. Łódź 1961.

SeroKa H.: Herby miast matopolskich do końca XVIII wieku. Warszawa 2002.

Słownik historyczno-geograficzny ziemi wieluńskiej w średniowieczu. Oprac. R. Rosin. Warszawa 1963.

SPerka J.: Otoczenie Wtadystawa Opolczyka w latach 1370-1401. Studium o elicie władzy $w$ relacjach $z$ monarcha. Katowice 2006.

Stelmach R.: Katalog średniowiecznych dokumentów przechowywanych w Archiwum Państwowym we Wrocławiu. Wrocław-Racibórz 2014.

StolarcZYK T.: Szlachta wieluńska od XIV do połowy XVI wieku. Wieluń 2005.

STRZYŻEWsKi W.: Herby rycerskie w godlach herbów miast śląskich, pomorskich i nowomarchijskich. W: Etos rycerski w Europie Środkowej $i$ Wschodniej od X do XV wieku. Red. W. Peltz, J. Dudek. Zielona Góra 1997.

Strzyżewski W.: Treści symboliczne herbów miejskich na Śląsku, Ziemi Lubuskiej i Pomorzu Zachodnim do końca XVIII wieku. Zielona Góra 1999.

SzCZerbik Z.: Herb miasta Praszki. W: Herby miast polskich w okresie zaborów (1772-1918). Materiały z sesji naukowej, Włocławek 5-6 grudnia 1996 r. Red. S.K. KuCZYŃsKI. Włoclawek 1999.

SzCZYGIelski W.: Dzieje ziemi wieluńskiej. Łódź 1969.

Szweda A.: Nieznana czternastowieczna pieczęć Łowicza. W: Heraldyka i okolice. Red. A. Rachuba, S. GórzyŃski, H. ManikowsKa. Warszawa 2002.

SzYMAŃski J.: Herbarz rycerstwa polskiego z XVI wieku. Warszawa 2001.

Szymański J.: Herbarz średniowiecznego rycerstwa polskiego. Warszawa 1993.

SzymaŃski J.: Nieznane źródto heraldyki polskiej z XVI wieku. „Studia Źródłoznawcze” 1990, T. $32 / 33$.

Szymański J.: W sprawie genezy polskich herbów miejskich. W: Spoleczeństwo Polski średniowiecznej. Zbiór studiów. Red. S.K. KuczyŃski. T. 6. Warszawa 1994.

Tomczyк D., Ziarko S.: Herby oraz inne symbole samorzqdowe miast i gmin województwa opolskiego. Opole 2000.

TRelińsKa B.: Gotyckie pismo epigraficzne w Polsce. Lublin 1991.

Wiesiolowski J.: Fundacje paulińskie XIV i XV wieku na tle ruchu fundacyjnego klasztorów w Polsce. „Studia Claromontana” 1985, T. 6.

Wojciechowski L.: Najstarsze klasztory paulinów w Polsce. Fundacja - uposażenie - rozwój do około 1430 roku. „Studia Claromontana” 1991, T. 11.

Wojciechowski L.: Ród Wieruszów do początku XV wieku. W: Ludzie i herby w dawnej Polsce. Red. P. Dymmel. Lublin 1995.

WóJcIK M.L.: Pieczęcie rycerstwa śląskiego w dobie przedhusyckiej. T. 1-2. Kraków-Wrocław 2018.

ZBudniewex J.: Kopiarz dokumentów konwentu Paulinów w Wieruszowie. „Archiwa, Biblioteki i Muzea Kościelne" 1973, T. 26.

ZbudnieweK J.H.: Katalog domów i rezydencji polskiej prowincji paulinów. „Nasza Przeszłość" 1969, T. 31. 


\section{Marek L. Wójcik}

The unknown fourteenth-century seal of Wieruszów: A contribution to research on the oldest coats of arms of the town and of its owners

Summary

The article has as its subject the coat of arms seal of Wieruszów that was used to authenticate a document from 28th January 1426. The seal is a point of departure for analysing the coat of arms of the town and of its owners. From the turn of the fourteenth century till 1467 the owners were representatives of the Wierusz family, who used Wieruszowa coat of arms. In historiography the seal had not been known before this discovery. The oldest coat of arms of Wieruszów was thought so far to be the following image: argent, a goat sable standing on the grass vert, bearing church gules with two towers of the same on the back. The representations of the goat originate from the seal as late as the end of the eighteenth century. The older seal recently discovered is dated for 1368-1426 and displays a coat of arms shield, party per pale, the dexter side checky of three and six gules and argent, on the sinister argent a demi-goat passant sable. In the rim there is the inscription "+ $\cdot \mathrm{S}$ (igillum) - C(ivitatis) - WERVSC[HOW]IENSIS". The iconography of the seal visibly relates to the coat of arms of the town's owners. They used the Wieruszowa coat of arms: argent, a goat half sable half checky gules and of the field. The artefact from 1426 and the coat of arms seals of the Wieruszów owners that they used between 1395 and 1448 have been analysed. The article demonstrates that the opinion that the owners laid a stag in their coat of arms instead of a goat is unfounded. This opinion has recently been put forward a lot in the research. The seal, unknown until recently, probably kept being used till the end of the fifteenth century. After the fire of the town, which broke out in 1497 or 1498, the seal was replaced with a new one. The iconography of the new seal was an updated one, since it combined the symbols associated with the town's founders and with feudal allegiance (a goat) and with manifesting the town's independence (a church façade with two towers). This is the current shape of the town's coat of arms.

Keywords: Wieruszów, the family of Wierusz, coat of arms, seal, goat, stag

\section{Marek L. Wójcik}

Das unbekannte Siegel von Wieruszów aus dem 14. Jahrhundert Ein Beitrag zur Forschung über die älteste Heraldik der Stadt und ihrer Besitzer

\section{Zusammenfassung}

Der Artikel ist dem Siegel der Stadt Wieruszów (dtsch. Weruschau) gewidmet, das auf einer Urkunde vom 28. Januar 1426 abgedruckt wurde. Der Siegelabdruck bietet einen Ausgangspunkt für die Analyse der Heraldik dieser Stadt, die vom Ende des dreizehnten Jahrhunderts bis 1467 den Vertretern der Familie Wierusz gehörte. In der Geschichtsschreibung blieb das Siegel bisher unbekannt. Als das älteste Stadtwappen galt allgemein die Abbildung des schwarzen, rechts schreitenden Ziegenbocks auf silbernem Grund, der auf dem grünen Rasen steht und eine rote zweitürmige Kirche auf dem Rücken trägt, dessen Darstellungen erst auf den Siegeln vom Ende des achtzehnten Jahrhunderts zu sehen waren. Das aufgefundene, für die 
Jahre 1368-1426 datierte Siegel stellt einen gespaltenen Wappenschild mit dem sechsreihigen Schachbrett zu drei Ziegeln rechts, einem halben aufgerichteten Ziegenbock links und folgender Umschrift dar: $+\cdot$ S(igillum) $\cdot$ C (ivitatis) $\cdot$ WERVSC[HOW]IENSIS. Seine Ikonografie bezieht sich eindeutig auf das Wappen der Stadtbesitzer, die sich mit dem einen halb schwarzen, halb rot-silber geschachten Ziegenbock darstellenden Siegel legitimierten. Auf der Grundlage der Analyse des Artefakts aus dem Jahre 1426 und der Wappensiegel der Herren von Wieruszów aus den Jahren 1395-1448 deutet der Autor darauf hin, dass es keine Begründung für die in der letzten Zeit in der Literatur verbreitete Meinung gibt, dass die Familie in ihrem Wappen einen Rehbock anstelle des Ziegenbocks getragen hätte. Das unbekannte Siegel wurde höchstwahrscheinlich bis Ende des fünfzehnten Jahrhunderts verwendet. Nach dem Stadtbrand im Jahre 1497 bzw. 1498 wurde es gegen ein neues getauscht, mit dem aktualisierten ikonografischen Inhalt, der einerseits eine sich direkt auf die Gründer der Stadt beziehende und die Feudalherrschaft vertretende Symbolik (Ziegenbock) verband, andererseits die Stadtunabhängigkeit manifestierte (Kirchenfassade mit zwei Türmen). In dieser Form funktioniert das Wappen bis zum heutigen Zeitpunkt.

Schlüsselwörter: Wieruszów, Familie Wierusz, Wappen, Siegel, Ziegenbock, Rehbock 